\title{
URBAN CLIMATE IN CENTRAL EUROPEAN CITIES AND GLOBAL CLIMATE CHANGE*
}

\author{
A BOKWA ${ }^{1}$, P DOBROVOLNÝ ${ }^{2}$, T GÁL $^{3}$, J GELETIČ $^{2}$, Á GULYÁS $^{3}$, M J HAJTO $^{4}$,

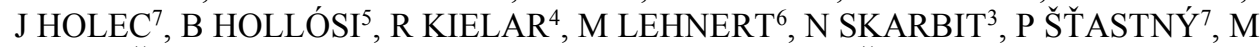 \\ $\breve{S} \mathrm{BEC}^{7}, \mathrm{~J}_{\mathrm{UNGER}}^{3}$, J P WALAWENDER ${ }^{4,1}$ and M ŽUVELA-ALOISE ${ }^{5}$ \\ ${ }^{1}$ Jagiellonian University, Institute of Geography and Spatial Management, Gronostajowa St. 7, 30-387 Kraków, Poland \\ ${ }^{2}$ Global Change Research Centre AS CR, Belidla St. 986/4a, 60300 Brno, Czech Republic \\ ${ }^{3}$ Department of Climatology and Landscape Ecology, University of Szeged, Egyetem u. 2., 6720 Szeged, Hungary \\ ${ }^{4}$ Institute of Meteorology and Water Management - National Research Institute, Piotra Borowego St. 14, 30-215 Kraków, Poland \\ ${ }^{5}$ Zentralanstalt für Meteorologie und Geodynamik, Hohe Warte St. 38, 1190 Vienna, Austria \\ ${ }^{6}$ Palacký University Olomouc, Krizkovskeho St. 511/8, 77147 Olomouc, Czech Republic \\ ${ }^{7}$ Slovak Hydrometeorological Institute, Jeseniova St. 17, 83315 Bratislava, Slovakia \\ E-mail: anita.bokwa@uj.edu.pl
}

\begin{abstract}
Summary: Urban areas are among those most endangered with the potential global climate changes. The studies concerning the impact of global changes on local climate of cities are of a high significance for the urban inhabitants' health and wellbeing. This paper is the final report of a project (Urban climate in Central European cities and global climate change) with the aim to raise the public awareness on those issues in five Central European cities: Szeged (Hungary), Brno (Czech Republic), Bratislava (Slovakia), Kraków (Poland) and Vienna (Austria). Within the project, complex data concerning local geomorphological features, land use and long-term climatological data were used to perform the climate modelling analyses using the model MUKLIMO_3 provided by the German Weather Service (DWD).
\end{abstract}

Key words: urban climate, climate change, urban climate model, heat load

\section{INTRODUCTION}

Global climate changes affect the environment in global, regional and local scales. Urban climate is a local scale phenomenon but it has direct and significant impact on 54\% of the total global population living in cities (data of 2014). The global urban population is expected to grow further, approximately $1.84 \%$ per year between 2015 and $2020,1.63 \%$ per year between 2020 and 2025, and $1.44 \%$ per year between 2025 and 2030 (Urban population growth 2015). Parallel, the global mean surface temperature change for the period 20162035 relative to $1986-2005$ will likely be in the range of $0.3^{\circ} \mathrm{C}$ to $0.7^{\circ} \mathrm{C}$, and relative to the average from year 1850 to 1900 , global surface temperature change by the end of the $21 \mathrm{st}$ century is projected to likely exceed $1.5^{\circ} \mathrm{C}$ (IPCC 2013). Urban areas are among those most endangered with the potential global climate changes. The heat load in cities is supposed to get intensified as global temperature increase will be superimposed on air temperature modifications characteristic for urban areas, e.g. the Urban Heat Island (UHI) effect. Those phenomena might have far-reaching health effects (e.g. Baccini et al. 2008). Therefore, the

\footnotetext{
${ }^{*}$ This paper is the edited version of the final report of the Urban climate in Central European cities and global climate change project, submitted in 2015.
} 
studies concerning the impact of global changes on local climate of cities are of a high significance for the urban inhabitants' health and wellbeing. In order to plan and undertake the mitigation actions in particular cities, it is necessary to recognize the possible range of heat load increase, in terms of both its magnitude and spatial extent.

The present paper shows the prediction of urban heat load increase by 2100 in five Central European cities: Kraków (Poland), Bratislava (Slovakia), Brno (Czech Republic), Szeged (Hungary) and Vienna (Austria). The heat load is defined as the mean annual number of the summer days, i.e. days with maximum temperature $\geq 25^{\circ} \mathrm{C}$. Numerous previous studies, completed for the cities mentioned, allowed to achieve the recognition of their present urban climate features (e.g. Unger et al. 2011, Unger et al. 2014, Dobrovolný et al. 2012, Dobrovolný 2013, Lapin and Melo 2011, Auer et al. 1989, Böhm 1998, Walawender et al. 2014, Bokwa 2010a, 2010b, Bokwa et al. 2015). The cities are located in large river valleys and the diversified relief is an important local climate factor (except Szeged, located in flat area), even though the cities are not placed in the mountains. The historical urban infrastructure of Kraków, Bratislava, Brno and Szeged has been significantly modified first due to the destruction during the Second World War and then due to spatial development during the communistic times. For example, unlike in most cities located in USA or West Europe, areas with high buildings can be found in the suburbs, while city centres comprise of 2-3-storey historical buildings. Therefore, urban climate of the cities included in the study is an outcome of complex interactions between land use/land cover and land forms. The modelling approach used is designed to evaluate possible changes in urban heat load under future climate conditions, taking under consideration the role of the relief in controlling the urban climate which is a unique feature comparing to other similar tools available. The longperspective aim of the study is to compare the values and spatial extent of the expected heat load increase among the cities included in the study, find the factors controlling those patterns and provide the city planners with information which can be implemented in the future urban development plans.

\section{THE STUDY AREAS AND METHODS}

In the present study, the analyses were performed for five cities, located in Central Europe. The basic features of the cities are described in Table 1.

Table 1 Basic data concerning the cities included in the study

\begin{tabular}{lccl}
\hline \multicolumn{1}{c}{ City (country) } & Area $\left(\mathrm{km}^{2}\right)$ & Altitude range (m a.s.l.) & Population (year) \\
\hline Kraków (Poland) & 327 & $145-459$ & $761,870(2014)$ \\
Bratislava (Slovakia) & 368 & $126-450$ & $419,670(2014)$ \\
Brno (Czech Republic) & 230 & $200-525$ & $377,400(2015)$ \\
Szeged (Hungary) & 281 & $46-143$ & $162,500(2015)$ \\
Vienna (Austria) & 414 & $141-581$ & $1,812,600(2015)$ \\
\hline
\end{tabular}

Kraków is a city in southern Poland, on the river Vistula. The city is located in a concave landform, i.e. in the river valley passing from west to east. The historical city centre is placed on the bottom of the river Vistula valley (at about $200 \mathrm{~m}$ a.s.l.), on a limestone tectonic horst (Wawel Hill), emerging from the river valley. To the north of the river Vistula and the city centre is the Kraków-Częstochowa Upland, built of limestone and marls, and its parts located close to Kraków reach up to $300 \mathrm{~m}$ a.s.l. The southern borders of the city run 
partially in the Carpathian Foothills, built of Flysch rocks, with an elevation up to $370 \mathrm{~m}$ a.s.l. in the area neighbouring Kraków. The river Vistula valley is narrow in the western part of Kraków (about $1 \mathrm{~km}$ ) and widens to about $10 \mathrm{~km}$ in the eastern part. In the western part of the valley, there are several limestone tectonic horsts, reaching about $350 \mathrm{~m}$ a.s.l., so the city area is not surrounded by hills only from the east. The urbanized areas can be found in the river valley with its terraces and in convex landforms to the south and north of the city centre. Height differences between the valley floor and the hilltops next to the city borders are about $100 \mathrm{~m}$, and the built-up areas do not reach those hilltops. Within the city borders, built-up areas cover $43.0 \%$ of the area, while agricultural and semi-natural areas amount to $41.3 \%$, and the remaining (green and water) areas cover $15.7 \%$. In the valley floor, many different land use types can be distinguished, while in the convex landforms south and north of the valley, only a few land use types can be found (Bokwa et al. 2015).

Bratislava is located in south-western Slovakia and it occupies both banks of the River Danube and the left bank of the River Morava. It is the country's largest city, situated only $60 \mathrm{~km}$ from the Austrian capital Vienna. Bordering Austria and Hungary, it is the only national capital that borders two independent countries (Swire 2006). The city has a total area of $368 \mathrm{~km}^{2}$. The historic city center is located between the Danube and south-eastern slopes of the Carpathian mountain range - Malé Karpaty. Several city districts or boroughs are not directly connected to the historical center, but are located more separately and connected to Bratislava through narrow urban regions. The largest and most distinct borough of Bratislava situated on the right bank of Danube is Petržalka. Significant feature in the region of Bratislava is the mentioned Malé Karpaty mountain range in the northern and western parts of the city. Several city boroughs are found on both sides of the mountain ridge and are situated at foothill or directly on its slopes. The most of city districts are however located in the lowlands, to the east and southeast at Podunajská nížina lowland and to the northwest at Záhorská nížina lowland. The city's lowest point is at the Danube at $126 \mathrm{~m}$ a.s.l., and the highest point is Devínska Kobyla at $514 \mathrm{~m}$. Complex orographic conditions in the Bratislava region generate a distinct and variable nature of the climate in the city and its surroundings. Especially the Malé Karpaty mountain range is affecting overall air circulation and thereby affecting most of climate characteristics in the city.

Brno is situated in the south-eastern part of the Czech Republic and it is the secondlargest city in the country. Brno area is characterized by a basin position with complex terrain. Altitudes range from $190 \mathrm{~m}$ to $479 \mathrm{~m}$, with the higher elevations lying largely in the western and northern parts of the region. Lower and flatter terrain is typical of the southern and eastern parts of the study area. There is a large water reservoir (area approximately $2.6 \mathrm{~km}^{2}$ ) located on the north-west border of the built-up part. The study area lies in one of the warmest and the driest regions in the Czech Republic. Mean annual temperature stands at $9.4^{\circ} \mathrm{C}$, while mean annual precipitation is around $500 \mathrm{~mm}$ (1961-2000 reference period).

Szeged is located in the Pannonian Plain in Central Europe. According to the climate classification system developed by Köppen, it belongs to temperate warm climate with a rather uniform annual distribution of precipitation (Kottek et al. 2006). The urbanized area covers only about $40 \mathrm{~km}^{2}$ of the city. The Tisza River is the axis of the town and the city has a regular avenue-boulevard structure. It is characterized by densely built up center, blocks of flats in the northern part, large area of family houses and warehouses mostly in western part (Unger 2004). In the study area, several database and input material is available from earlier studies, e.g. parameters used in the LCZ system and a set of other data (Rapid eye satellite images, CORINE land cover, road database, etc.) (Lelovics et al. 2014). 

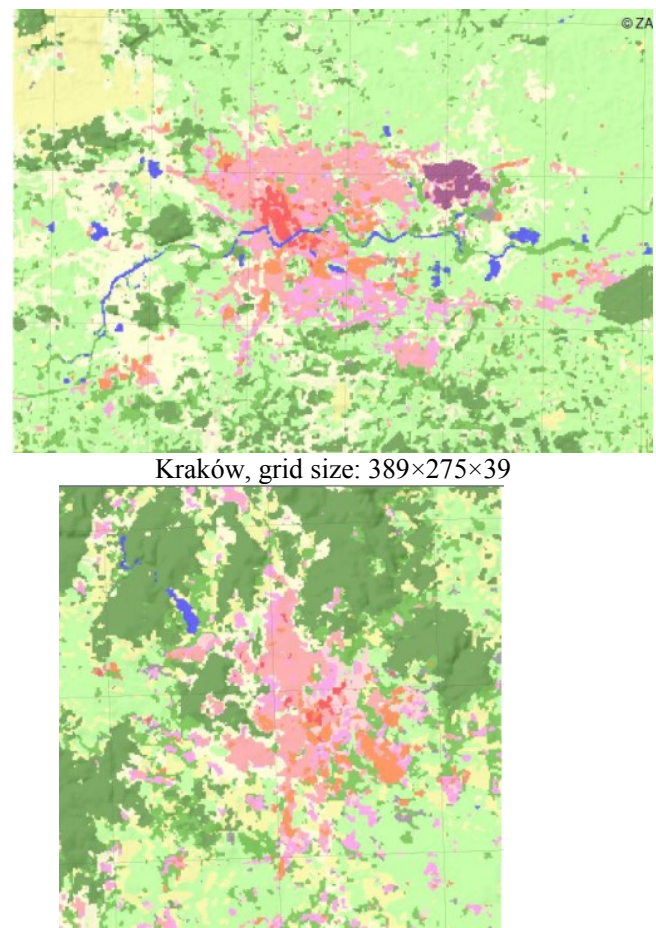

Brno, grid size: $250 \times 250 \times 39$

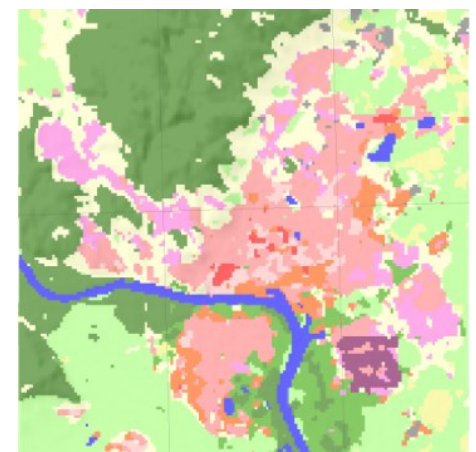

Bratislava, grid size: $160 \times 160 \times 39$

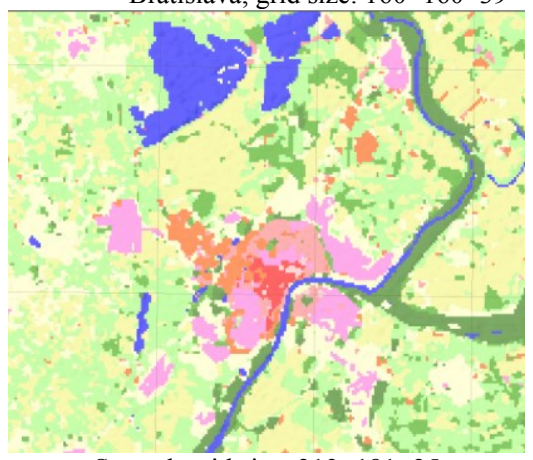

Szeged, grid size: $213 \times 181 \times 25$

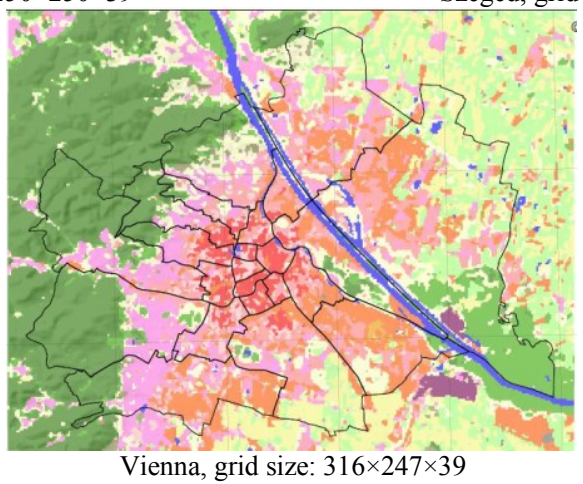

Fig. 1 Land use/land cover for the cities studied and their surroundings, presented with the LCZ method

Vienna is the capital city of Austria and the largest city used in this study. It is located at the easternmost extension of the Alps in a transition zone to the Pannonian Plain with the Danube River passing through the city. The City of Vienna covers an area of 41,487 ha from which $35.6 \%$ are buildings, $45.5 \%$ are green areas, $4.6 \%$ is water and $14.3 \%$ are traffic surfaces. The highest elevation is the Hermannskogel in Wienerwald $(543 \mathrm{~m})$ and the lowest point $(151 \mathrm{~m})$ is in the Lobau, east of the city center (Stadt Wien 2015). The urbanized area is characterized by the historical center surrounded by a green belt, dense built-up areas in the inner districts and low-density residential areas on the hillsides in the western part of the 
city and in the flat terrain in the south and east direction. Most of the industrial areas are located in the eastern and southern part of the city.

In each of the cities studied, the land use pattern is different. In order to obtain comparable data on land use/land cover for all the cities, the method of Local Climate Zones was used (see section 4.2). The results are presented in Fig. 1.

Table 2 presents the share of particular LCZ classes in each city and its surroundings (i.e. in the domains shown in Fig. 1). It can be seen that some LCZ classes cannot be found or their share is very little in all cities: 1 (compact high-rise), 4 (open high-rise), 7 (lightweight low-rise), B (scattered trees), G (water). There is no one single LCZ that would have a dominating share in all cities; on the contrary, the land use/land cover structure is different for each city. Additionally, Fig. 1 shows that the spatial pattern of particular LCZ is different in each city, i.e. there are no regular zones surrounding the urban core area but there is a mosaic of various LCZ types.

Table 2 Share (\%) of particular LCZ classes in the total area of the domain taken into analyses for each city studied

\begin{tabular}{|c|c|c|c|c|c|c|c|c|c|c|c|c|c|c|c|c|c|}
\hline \multirow[t]{2}{*}{ City } & \multicolumn{17}{|c|}{ LCZ classes } \\
\hline & 1 & 2 & 3 & 4 & 5 & 6 & 7 & 8 & 9 & 10 & $\mathbf{A}$ & B & $\mathrm{C}$ & D & $\mathbf{E}$ & $\mathbf{F}$ & G \\
\hline Kraków & - & 0.6 & 0.2 & . & 6.5 & 2.9 & 0.0 & 1.8 & 14.4 & 0.6 & 8.3 & 8.1 & - & 50.1 & 0.3 & 5.2 & 1.0 \\
\hline Bratislava & - & 0.7 & 2.8 & . & -13.0 & 6.2 & - & 5.2 & 15.4 & 24.1 & 4.7 & - & 20.9 & 1.4 & 2.9 & 2.6 & - \\
\hline Brno & - & 0.6 & 7.4 & . & -4.3 & 5.0 & 1.4 & 3.3 & 6.8 & 32.6 & 20.7 & - & 6.7 & 3.2 & 7.6 & 0.4 & - \\
\hline Szeged & - & 0.7 & 0.4 & . & -3.6 & 5.1 & - & 4.8 & 16.4 & 6.4 & 8.5 & - & 23.5 & - & 27.1 & 3.4 & - \\
\hline Vienna & - & 2.1 & 2.6 & . & $-\quad 8.8$ & 8.5 & 0.2 & 10.6 & 11.4 & 0.6 & 21.9 & 7.2 & 0.7 & 12.7 & 0.1 & 9.9 & 2.6 \\
\hline
\end{tabular}

\section{METEOROLOGICAL DATA}

Meteorological data were used in the study for several purposes. In each city, daily data from a rural and from an urban station were used, for a period of 30 years (1971-2000 and 1981-2010), concerning air temperature, humidity and wind speed and direction. The stations are listed in Table 3.

Table 3 Meteorological stations used in the study

\begin{tabular}{cllcc}
\hline City & \multicolumn{1}{c}{ Station name } & Land use & Coordinates & Altitude (m a.s.l.) \\
\hline Bratislava & Bratislava, airport & Rural & $48^{\circ} 10^{\prime} \mathrm{N}, 17^{\circ} 12^{\prime} \mathrm{E}$ & 128 \\
& Bratislava, Mlynská dolina & Urban & $48^{\circ} 09^{\prime} \mathrm{N}, 17^{\circ} 04^{\prime} \mathrm{E}$ & 180 \\
\multirow{3}{*}{ Brno } & Brno, Tuřany airport & Rural & $49^{\circ} 09^{\prime} \mathrm{N}, 16^{\circ} 41^{\prime} \mathrm{E}$ & 241 \\
& Brno, Mendel Sqr. & Urban & $49^{\circ} 11^{\prime} \mathrm{N}, 16^{\circ} 36^{\prime} \mathrm{E}$ & 206 \\
Kraków & Balice airport & Rural & $50^{\circ} 04^{\prime} \mathrm{N}, 19^{\circ} 47^{\prime} \mathrm{E}$ & 241 \\
& Botanical Garden & Urban & $50^{\circ} 03^{\prime} \mathrm{N}, 19^{\circ} 57^{\prime} \mathrm{E}$ & 206 \\
Szeged & HMS meteorological station & Rural & $46^{\circ} 15^{\prime} \mathrm{N}, 20^{\circ} 05^{\prime} \mathrm{E}$ & 79 \\
& HMS climate station & Urban & $46^{\circ} 15^{\prime} \mathrm{N}, 20^{\circ} 08^{\prime} \mathrm{E}$ & 81 \\
Vienna & Groß Enzersdorf & Rural & $48^{\circ} 11^{\prime} \mathrm{N}, 16^{\circ} 33^{\prime} \mathrm{E}$ & 153 \\
& Innere Stadt & Urban & $48^{\circ} 11^{\prime} \mathrm{N}, 16^{\circ} 22^{\prime} \mathrm{E}$ & 177 \\
\hline
\end{tabular}

The usage of meteorological data in cuboid method (section 4.1) was connected first with establishment of the threshold values; daily data from the 30 -year period were used to obtain for each city, for the rural station, the lowest (cmin) and the highest (cmax) values of mean daily air temperature $(\mathrm{T})$, relative humidity $(\mathrm{rh})$ and wind speed $(\mathrm{v})$, at which, at the urban station, the maximum air temperature was $\geq 25^{\circ} \mathrm{C}$. The combinations of those threshold 
Bokwa A, Dobrovolný P, Gál T, Geletič J, Gulyás Á, Hajto MJ, Holec J, Hollósi B, Kielar R, Lehnert M, Skarbit $N$, Štastný $P$, Švec $M$, Unger J, Walawender JP, Žuvela-Aloise $M$

values made the corners of a "cuboid" (Fig. 2), constructed separately for each city. Then the 30 -year data were used to obtain the spatial pattern of mean annual number of days with tmax $\geq 25^{\circ} \mathrm{C}$ for each city, for the areas presented in Fig. 1, with the usage of MUKLIMO_3 and the cuboid method. The 30 -year data were also used as a reference series for the comparison with modelled data, for each city.

\section{METHODS}

\subsection{MUKLIMO}

MUKLIMO_3 (in German: 3D Mikroskaliges Urbanes KLIma MOdell) is a nonhydrostatic micro-scale model with z-coordinates, which solves the Reynolds-averaged Navier-Stokes equations to simulate atmospheric flow fields in presence of buildings (Sievers and Zdunkowski 1985, Sievers 1990, 1995). The thermo-dynamical version of the model includes prognostic equations for atmospheric temperature and humidity, the parameterization of unresolved buildings, short-wave and long-wave radiation, balanced heat and moisture budgets in the soil (Sievers et al. 1983) and a vegetation model based on Siebert et al. (1992). The numerical approach for the calculation of short-wave irradiances at the ground, the walls and the roof of buildings in an environment with unresolved built-up is described by Sievers and Früh (2012). The flow between buildings is parameterized through a porous media approach for unresolved buildings (Gross 1989). The model uses highresolution orography and land use distribution data. For each land use class, a set of parameters is defined to describe land use properties and urban structures: fraction of built area $\left(\gamma_{b}\right)$, mean building height $\left(h_{b}\right)$, wall area index $\left(\mathrm{w}_{\mathrm{b}}\right)$, fraction of pavement of the nonbuilt area $(v)$, fraction of tree cover $\left(\sigma_{t}\right)$ and fraction of low vegetation of the remaining surface $\left(\sigma_{c}\right)$, height $\left(h_{c}\right)$ (Table 4$)$ and leaf area index $\left(\mathrm{LAI}_{\mathrm{c}}\right)$ of the canopy layer as well as mean height $\left(\mathrm{h}_{\mathrm{t}}\right)$ and leaf area index $\left(\mathrm{LAI}_{\mathrm{t}}\right)$ of the trees with separated values for the tree trunk and the tree crown area. The model does not include cloud processes, precipitation, horizontal runoff or anthropogenic heat.

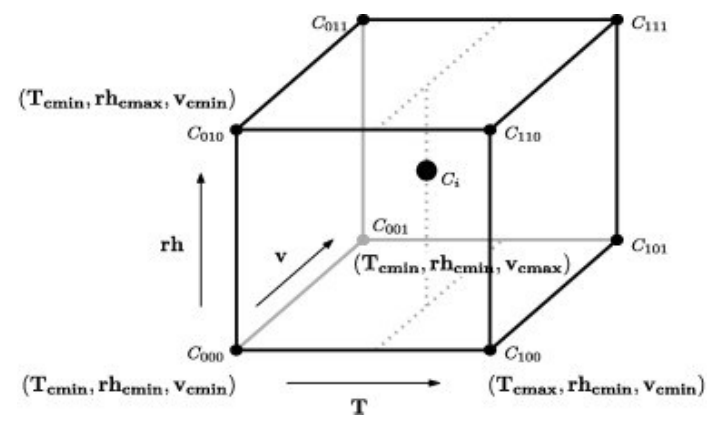

Fig. 2 The concept of the cuboid method (Žuvela-Aloise et al. 2014, Früh et al. 2011) 
Table 4 Parameters for land cover properties in MUKLIMO_3 model: fraction of built area $\left(\gamma_{b}\right)$, mean building height $\left(h_{b}\right)$, wall area index $\left(w_{b}\right)$, fraction of pavement $(v)$, fraction of tree cover $\left(\sigma_{t}\right)$, fraction of low vegetation $\left(\sigma_{c}\right)$, tree height $\left(h_{t}\right)$ and height of the low vegetation $\left(h_{c}\right)$. Fractions $\gamma_{b}$ and $\sigma_{t}$ are relative to the total grid cell area. Fraction $v$ is relative to the area without buildings and trees and $\sigma_{c}$ is relative to the remaining surface

\begin{tabular}{|c|c|c|c|c|c|c|c|c|c|}
\hline & Land use class & $\gamma_{b}(\%)$ & $h_{b}(\mathrm{~m})$ & $\boldsymbol{w}_{b}$ & $\begin{array}{c}v \\
(\%) \\
\end{array}$ & $\sigma_{t}(\%)$ & $\sigma_{c}(\%)$ & $\begin{array}{c}h_{t} \\
(\mathbf{m})\end{array}$ & $h_{c}(\mathbf{m})$ \\
\hline 1 & Compact high-rise & & & & & & & & \\
\hline 2 & Compact midrise & 0.40 & 15.00 & 3.42 & 0.60 & 0.00 & 0.80 & 0 & 0.30 \\
\hline 3 & Compact low-rise & 0.40 & 8.40 & 2.40 & 0.40 & 0.00 & 0.80 & 0 & 0.30 \\
\hline 4 & Open high-rise & & & & & & & & \\
\hline 5 & Open midrise & 0.20 & 18.60 & 4.40 & 0.60 & 0.00 & 0.80 & 0 & 0.30 \\
\hline 6 & Open low-rise & 0.20 & 6.50 & 2.10 & 0.40 & 0.00 & 0.70 & 0 & 0.30 \\
\hline 7 & Lightweight low-rise & 0.75 & 3.00 & 1.80 & 0.20 & 0.00 & 0.30 & 0 & 0.30 \\
\hline 8 & Large low-rise & 0.30 & 7.00 & 2.00 & 0.80 & 0.00 & 0.80 & 0 & 0.30 \\
\hline 9 & Sparsely built & 0.10 & 6.00 & 2.10 & 0.20 & 0.00 & 0.80 & 0 & 0.30 \\
\hline 10 & Heavy industry & 0.30 & 7.00 & 2.00 & 0.80 & 0.00 & 0.80 & 0 & 0.30 \\
\hline A & Dense trees & 0.00 & 0.00 & 0.00 & 0.00 & 0.80 & 0.90 & 17 & 0.50 \\
\hline $\mathrm{B}$ & Scattered trees & 0.00 & 0.00 & 0.00 & 0.00 & 0.40 & 0.90 & 9 & 0.50 \\
\hline $\mathrm{C}$ & Bush. scrub & 0.00 & 0.00 & 0.00 & 0.00 & 0.40 & 0.90 & 1.5 & 0.50 \\
\hline $\mathrm{D}$ & Low plants & 0.00 & 0.00 & 0.00 & 0.00 & 0.00 & 1.00 & 0 & 0.50 \\
\hline $\mathrm{E}$ & Bare rock or paved & 0.00 & 0.00 & 0.00 & 0.95 & 0.00 & 0.01 & 0 & 0.30 \\
\hline $\mathrm{F}$ & Bare soil or sand & 0.00 & 0.00 & 0.00 & 0.00 & 0.00 & 0.01 & 0 & 0.30 \\
\hline G & Water & 0.00 & 0.00 & 0.00 & -1.00 & 0.00 & 0.01 & 0 & 0.30 \\
\hline
\end{tabular}

In order to calculate climatic indices, such as the mean annual number of summer days, the dynamical modelling approach is combined with the so-called "cuboid method" (Früh et al. 2011, Žuvela-Aloise et al. 2014). The cuboid method refers to a tri-linear interpolation of meteorological fields derived by single-day simulations from an urban climate model. The simulations are performed for a set of idealized weather patterns for potential situations where a heat load exceedance in the urban centre could occur. Eight simulations with duration of 24 hours for two prevailing wind directions are calculated representing the cuboid corners (Fig. 2). Calculation of climatic indices for 30-year climatic periods is based on maximum temperature fields from the 8 single-day simulations using daily time series of $\mathrm{T}$, rh and $\mathrm{v}$, including hourly wind direction from a reference station as input.

\subsection{Local Climate Zones}

The Local Climate Zone (LCZ) classification (Stewart and Oke 2012) is an outstanding concept for the climate-related classification of urban areas in global scale. Although it was originally designed for meta-data communication in observational urban heat island studies, its possible applications are numerous. One of the most important ones is the possibility to use these zones for the input of different climate or weather models in order to better represent urban areas. The use of this concept in these models is advantageous because this classification is based on the thermal characteristics of the urban areas, and it is connected to the most obvious alteration of the climate in urban areas, the urban heat island (Stewart 2011). Fig. 3 contains the LCZ classes and definitions. 
Bokwa A, Dobrovolný P, Gál T, Geletič J, Gulyás Á, Hajto MJ, Holec J, Hollósi B, Kielar R, Lehnert M, Skarbit N, Štastný P, Švec M, Unger J, Walawender JP, Žuvela-Aloise $M$

\begin{tabular}{|c|c|c|c|}
\hline Built types & Definition & Land cover types & Definition \\
\hline I. Com & $\begin{array}{l}\text { Dense mix of tall buildings to tens of } \\
\text { stories. Few or no trees. Land cover } \\
\text { mostly paved. Concrete, steel, stone, } \\
\text { and glass construction materials. }\end{array}$ & A. Der & $\begin{array}{l}\text { Heavily wooded landscape of } \\
\text { deciduous and/or evergreen trees. } \\
\text { Land cover mostly pervious (low } \\
\text { plants). Zone function is natural } \\
\text { forest, tree cultivation, or urban park. }\end{array}$ \\
\hline 2. Co & $\begin{array}{l}\text { Dense mix of midrise buildings ( } 3-9 \\
\text { stories). Few or no trees. Land cover } \\
\text { mostly paved. Stone, brick, tile, and } \\
\text { concrete construction materials. }\end{array}$ & B. Scattered trees & $\begin{array}{l}\text { Lightly wooded landscape of } \\
\text { deciduous and/or evergreen trees. } \\
\text { Land cover mostly pervious (low } \\
\text { plants). Zone function is natural } \\
\text { forest, tree cultivation, or urban park. }\end{array}$ \\
\hline 3. Comp & $\begin{array}{l}\text { Dense mix of low-rise buildings ( } 1-3 \\
\text { stories). Few or no trees. Land cover } \\
\text { mostly paved. Stone, brick, tile, and } \\
\text { concrete construction materials. }\end{array}$ & C. Bush, scrub & $\begin{array}{l}\text { Open arrangement of bushes, shrubs, } \\
\text { and short, woody trees. Land cover } \\
\text { mostly pervious (bare soil or sand). } \\
\text { Zone function is natural scrubland or } \\
\text { agriculture. }\end{array}$ \\
\hline 4. Op & $\begin{array}{l}\text { Open arrangement of tall buildings to } \\
\text { tens of stories. Abundance of pervious } \\
\text { land cover (low plants, scattered } \\
\text { trees). Concrete, steel, stone, and } \\
\text { glass construction materials. }\end{array}$ & D. L & $\begin{array}{l}\text { Featureless landscape of grass or } \\
\text { herbaceous plants/crops. Few or } \\
\text { no trees. Zone function is natural } \\
\text { grassland, agriculture, or urban park. }\end{array}$ \\
\hline & $\begin{array}{l}\text { Open arrangement of midrise buildings } \\
\text { (3-9 stories). Abundance of pervious } \\
\text { land cover (low plants, scattered } \\
\text { trees). Concrete, steel, stone, and } \\
\text { glass construction materials. }\end{array}$ & E. Bare rock or $p$ & $\begin{array}{l}\text { Featureless landscape of rock or } \\
\text { paved cover. Few or no trees or } \\
\text { plants. Zone function is natural desert } \\
\text { (rock) or urban transportation. }\end{array}$ \\
\hline 6. 0 & $\begin{array}{l}\text { Open arrangement of low-rise buildings } \\
\text { (I-3 stories). Abundance of pervious } \\
\text { land cover (low plants, scattered trees). } \\
\text { Wood, brick, stone, tile, and concrete } \\
\text { construction materials. }\end{array}$ & F. Bar & $\begin{array}{l}\text { Featureless landscape of soil or sand } \\
\text { cover. Few or no trees or plants. } \\
\text { Zone function is natural desert or } \\
\text { agriculture. }\end{array}$ \\
\hline 7. Lightw & $\begin{array}{l}\text { Dense mix of single-story buildings. } \\
\text { Few or no trees. Land cover mostly } \\
\text { hard-packed. Lightweight construction } \\
\text { materials (e.g., wood, thatch, } \\
\text { corrugated metal). }\end{array}$ & G. Water & $\begin{array}{l}\text { Large, open water bodies such as seas } \\
\text { and lakes, or small bodies such as } \\
\text { rivers, reservoirs, and lagoons. }\end{array}$ \\
\hline 8. Large & $\begin{array}{l}\text { Open arrangement of large low-rise } \\
\text { buildings ( } 1-3 \text { stories). Few or no } \\
\text { trees. Land cover mostly paved. } \\
\text { Steel, concrete, metal, and stone } \\
\text { construction materials. }\end{array}$ & \multicolumn{2}{|c|}{$\begin{array}{l}\text { Variable or ephemeral land cover properties that change } \\
\text { significantly with synoptic weather patterns, agricultural practices, } \\
\text { and/or seasonal cycles. }\end{array}$} \\
\hline$\theta$ & $\begin{array}{l}\text { Sparse arrangement of small or } \\
\text { medium-sized buildings in a natural } \\
\text { setting. Abundance of pervious land } \\
\text { cover (low plants, scattered trees). }\end{array}$ & s. snow cover & $\begin{array}{l}\text { Leafless deciduous trees (e.g., winter). } \\
\text { Increased sky view factor. Reduced } \\
\text { albedo. } \\
\text { Snow cover }>10 \mathrm{~cm} \text { in depth. Low } \\
\text { admittance. High albedo. }\end{array}$ \\
\hline 10. Heavy industry & $\begin{array}{l}\text { Low-rise and midrise industrial struc- } \\
\text { tures (towers, tanks, stacks). Few or } \\
\text { no trees. Land cover mostly paved } \\
\text { or hard-packed. Metal, steel, and } \\
\text { concrete construction materials. }\end{array}$ & $\begin{array}{l}\text { d. dry ground } \\
\text { w. wet ground }\end{array}$ & $\begin{array}{l}\text { Parched soil. Low admittance. Large } \\
\text { Bowen ratio. Increased albedo. } \\
\text { Waterlogged soil. High admittance. } \\
\text { Small Bowen ratio. Reduced albedo. }\end{array}$ \\
\hline
\end{tabular}

Fig. 3 Local Climate Zones classes and definitions (Stewart and Oke 2012)

The LCZ system was initially designed for the classification of urban measurement sites (Stewart and Oke 2012), but meanwhile several methods for LCZ mapping have been proposed (Bechtel and Daneke 2012, Lelovics et al. 2014, Geletič and Lehnert 2016, Bechtel 
et al. 2015). Our study concentrates on 5 different cities and for each city different databases and surface data are available. For this reason we had to choose a simple method for mapping, moreover the same method had to be used in all of the cities. Therefore, the same input data needed had to be available in all cities. The only suitable method in this situation is the Bechtel-method. It applies free-access satellite images, free software and it can be handled without expert remote sensing knowledge. The methodology uses two software packages: Google Earth and SAGA-GIS. As an input data, it applies globally available Landsat satellite images. The workflow consist two main steps (Bechtel et al. 2015).

First, typical LCZ areas (training areas) have to be located in the study area; this part is carried out in Google Earth. The training areas are stored in a $\mathrm{kml}$ file containing a set of polygons for the different $\mathrm{LCZ}$ types and also a rectangle defining the border of the examined area. This kml file is used for the second part of the process which is carried out in SAGAGIS. Secondly, in SAGA-GIS the Landsat images and the vector file (containing the training areas) have to be preprocessed. The Landsat scene is cut with the border of study area in order to decrease the computation time, and the imagery is resampled to $100 \mathrm{~m}$ from the original $30 \mathrm{~m}$ to get a representation of the spectral signal of local scale urban structures rather than smaller objects. Finally, the classification is conducted with the built in random forest classifier based on the Landsat images and the training area polygons. The classifier calculates the most likely LCZ type and the probabilities for all LCZ classes for each pixel.

For the study areas included in the present paper, we used all spectral bands of 19 Landsat 7 and 8 images (Bratislava: 3 images, Brno: 4, Kraków: 4, Szeged: 5, Vienna: 3). The use of multiple images from different seasons is advantageous, as with more spectral information the classification gives better results. The scenes were obtained from USGS (earthexplorer.usgs.gov). The criterion of the selection of these images was to ensure the absence of clouds. The LCZ classification outcome for particular cities is shown in Fig. 1.

\subsection{EURO-CORDEX}

Climate models provide key information on the impacts of $21^{\text {st }}$ century climate change but are limited in their capacity to represent the relatively small scales needed for decision making on adaptation. Large collaborative research projects such as EURO-CORDEX (Jacob et al. 2013) have generated climate change scenarios via Regional Climate Models (RCMs). EURO-CORDEX simulations use the new Representative Concentration Pathways (RCPs) defined in the Fifth Assessment Report of the IPCC (Moss et al. 2010, IPCC 2013). RCPs do not identify socioeconomic scenarios; they express the change in radiative forcings, introduced by altered land use patterns at the end of the twenty-first century relative to preindustrial conditions (Table 5). For instance, the EURO-CORDEX simulations consider the RCPs scenarios corresponding to stabilization of radiative forcing after the $21^{\text {st }}$ century at 4.5 $\mathrm{Wm}^{-2}$ (RCP4.5) (Smith and Wigley 2006, Clarke et al. 2007, Wise et al. 2009), rising radiative forcing crossing $8.5 \mathrm{Wm}^{-2}$ at the end of $21^{\text {st }}$ century (RCP8.5) (Riahi et al. 2007), and peaking radiative forcing within the $21^{\text {st }}$ century at $3.0 \mathrm{Wm}^{-2}$ and declining afterwards (RCP2.6) (van Vuuren et al. 2007).

The EURO-CORDEX simulations not only consider the new RCP scenarios, they increase the spatial resolution based on multiple dynamical and empirical-statistical downscaling. The members of the ensemble are forced by multiple global climate models from the Coupled Model Intercomparison Project (CMIP5) and the simulations focus on gridsizes of about $12 \mathrm{~km}\left(0.11^{\circ}, \mathrm{EUR}-11\right)$ and $50 \mathrm{~km}\left(0.44^{\circ}\right.$, EUR-44) for the complete European model domain. 
Bokwa A, Dobrovolný P, Gál T, Geletič J, Gulyás Á, Hajto MJ, Holec J, Hollósi B, Kielar R, Lehnert M, Skarbit N, Štastný P, Švec M, Unger J, Walawender JP, Žuvela-Aloise $M$

Table 5 Characteristics of the new Representative Concentration Pathways (RCPs)

\begin{tabular}{ccccccc}
\hline Name & $\begin{array}{c}\text { Radiative } \\
\text { forcing }\end{array}$ & $\begin{array}{c}\text { CO } \mathbf{e q} \text {. } \\
\mathbf{( p p m )}\end{array}$ & $\begin{array}{c}\text { Temp. } \\
\text { anomaly } \\
\left({ }^{\circ} \mathbf{C}\right)\end{array}$ & Pathway & $\begin{array}{c}\text { SRES } \\
\text { temp. eq. }\end{array}$ & $\begin{array}{c}\text { Number of } \\
\text { experiments }\end{array}$ \\
\hline RCP8.5 & $\begin{array}{c}8.5 \mathrm{Wm}^{-2} \\
\text { in } 2100\end{array}$ & 1370 & 4.9 & Rising & SRES A1FI & 7 \\
RCP4.5 & $\begin{array}{c}4.5 \mathrm{Wm}^{-2} \\
\text { past } 2100\end{array}$ & 650 & 2.4 & $\begin{array}{c}\text { Stabilization } \\
\text { without } \\
\text { overshoot } \\
\text { Peak and } \\
\text { decline }\end{array}$ & SRES B1 & 7 \\
RCP2.6 & $\begin{array}{c}2.6 \mathrm{Wm}^{-2} \\
\text { by } 2100\end{array}$ & 490 & 1.5 & None & 1 \\
\hline
\end{tabular}

For this study, five different GCMs and three different RCMs have been used for the establishment of one simulation for RCP2.6 and seven simulations for RCP4.5 and RCP8.5 for the EUR-11 domain (Table 6). All changes in output variables (mean temperature, relative humidity, wind speed and direction) have been analysed for the city areas using daily data for three time periods: 1971-2000, 2021-2050 and 2071-2100.

Table 6 GCM-RCM model chains used to generate the different climate change projections used in this study

\begin{tabular}{lcc}
\hline Model & $\begin{array}{c}\text { RCP2.6 } \\
\text { Near-surface temperature [K] } \\
\text { Near-surface relative humidity [\%] } \\
\text { Eastward Near-Surface Wind [ms }{ }^{-1} \text { ] } \\
\text { Northward Near-Surface Wind [ms }\end{array}$ \\
\hline EUR-11_CNRM-CERFACS-CNRM-CM5 *_SMHI-RCA4 & $\checkmark$ & $\checkmark$ \\
EUR-11_ICHEC-EC-EARTH_*_SMHI-RCA4 & $\checkmark$ & $\checkmark$ \\
EUR-11_ICHEC-EC-EARTH_*_KNMI-RACMO22E & $\checkmark$ & $\checkmark$ \\
EUR-11_ICHEC-EC-EARTH_*_DMI-HIRHAM5 & $\checkmark$ & $\checkmark$ \\
EUR-11_IPSL-IPSL-CM5A-MR_*_SMHI-RCA4 & $\checkmark$ & $\checkmark$ \\
EUR-11_MPI-M-MPI-ESM-LR_*_SMHI-RCA4 & $\checkmark$ & $\checkmark$ \\
EUR-11_MOHC-HadGEM2-ES_*_SMHI-RCA4 & & $\checkmark$ \\
\hline
\end{tabular}

The outputs of the climate models do not offer perfect results as they describe complex processes and interactions. We can observe systematic errors in the outputs. To minimize this error we should use error correction processes. There are abundant of known processes, in this study we used a bias correction method.

The applied correction method is based on that we can completely describe the statistical properties of given datasets with their distribution and probability functions. So we can say that two data series are the same if their distribution and probability functions are the same (Formayer and Haas 2009). Thus if we want to correct a dataset based on its statistical properties we have to achieve that the distribution function will be the same of the measurements. Therefore to apply this method we should have dataset from measurements for a given time period. For this common period we suit the distribution functions of the measurement and the model with correction factors and we assume that the deviation will be permanent. In case of temperature the correction factors are the deviations of the percentiles.

In this study we used the 1971-2000 time period as reference period. We calculated the $1 \%$ percentiles and their deviation for the datasets of the measurement and the model simulations. We corrected the temperature datasets for the 2021-2050 and 2071-2100 periods based on the deviation of the reference period. In case of the relative humidity we took into consideration the corrected temperature data. The other correction that we made is 
the correction of the temperature gradient in height. We surveyed the altitude for each city and for each grid points which are the nearest to the city in the model outputs. We calculated the deviation and took into account the decrease of the temperature in height applying the $0.65^{\circ} \mathrm{C} / 100 \mathrm{~m}$ value.

\subsection{Estimation of the change in heat load}

For the present study, the heat load is expressed in the mean annual number of days with maximum air temperature $\geq 25^{\circ} \mathrm{C}$, i.e. summer days. The change in the heat load due to predicted climate changes is then defined as the difference in the mean annual number of summer days between a 30-year period representing the present conditions, 1971-2000, and two periods representing future conditions: 2021-2050 and 2071-2100. Therefore, first the spatial pattern on mean annual number of summer days, for each city and period considered, was obtained with the usage of MUKLIMO_3 and cuboid method. For each of the two future periods (2021-2050 and 2071-2100), the calculations were made separately for each climate scenario (i.e. RCP2.6, RCP4.5 and RCP8.5). For RCP2.6, the results obtained with one model were used, while for RCP4.5 and RCP8.5, mean values from seven models were used (see Table 6). The comparative analysis of the patterns allows to define areas in particular cities which are and/or are supposed to be the "hot spots" and "cold spots", and which might experience the largest and the smallest changes in the heat load in the future. The changes of the heat load can be also calculated separately for areas with particular LCZ type in order to show whether all kinds of land use/land cover will react to the climatic changes in a similar way. For each city and period, mean, maximum and minimum number of summer days for the whole domain considered was calculated. The mean value is representative for the whole area, while maximum and minimum values describe extreme conditions occurring in the area and constitute the range of the phenomenon' variability. The changes can be expressed in absolute numbers or in percentage; the latter is especially useful in comparative studies between the cities.

\section{RESULTS}

\subsection{Reference}

The map of the summer days calculated using the measured climate data in Szeged has a characteristic spatial pattern (Fig. 4). In the city center, we find the highest values (about 100-110 days) in the time period 1981-2010. In the less dense

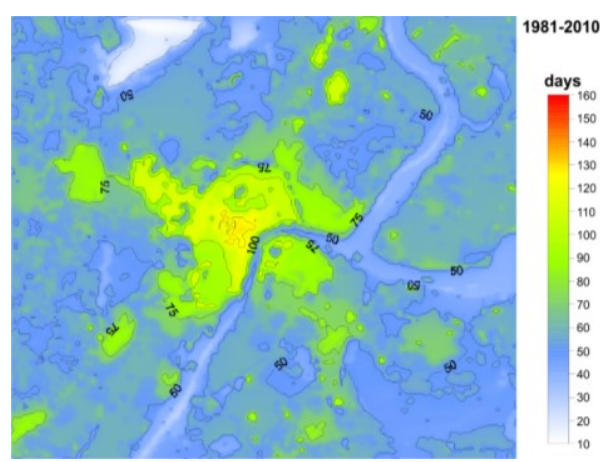

Fig. 4 Mean annual number of summer days in Szeged in the period 1981-2010 using the measured data

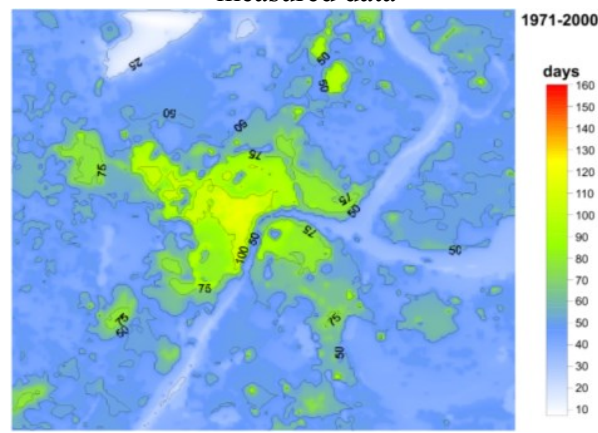

Fig. 5 Mean annual number of summer days in Szeged in the period 1971-2000 using the data of the climate models 

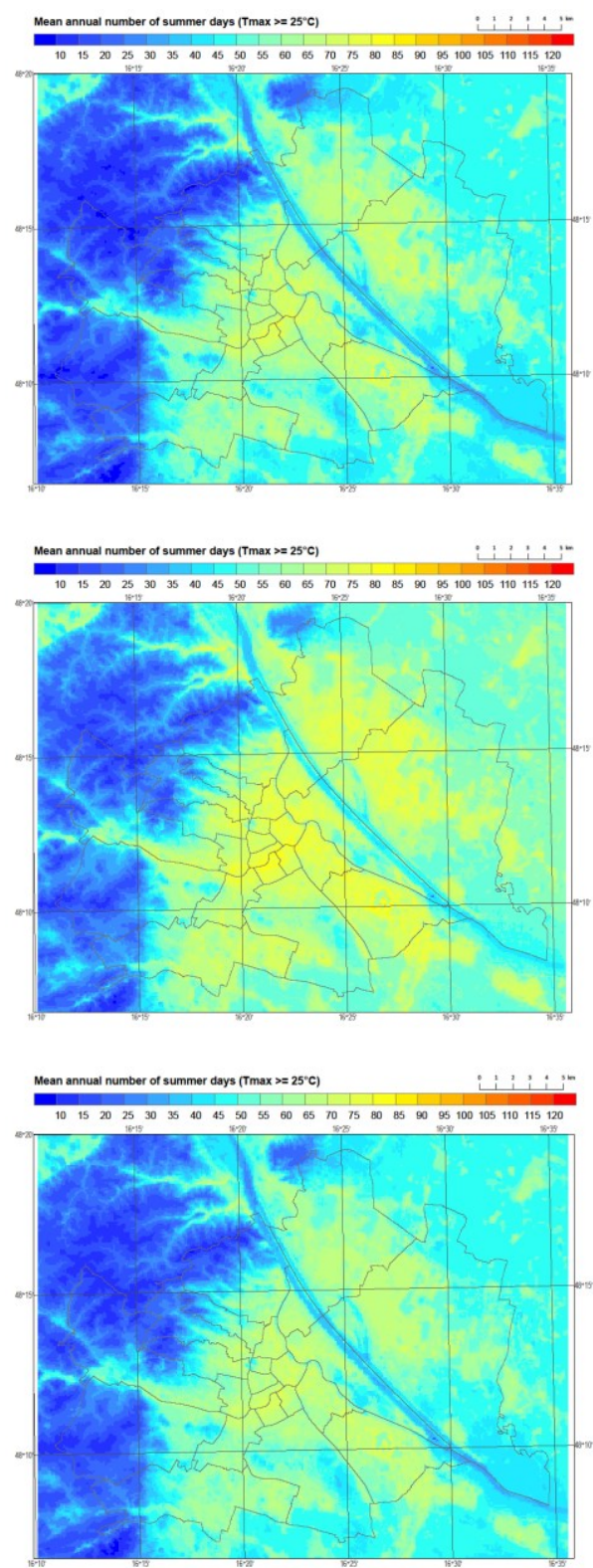

Fig. 6 Mean annual number of summer days in Vienna in the period 1971-2010 (top) and 1981-2010 (center) using the measured data and 1971-2000 (bottom) using the data of the climate models

landforms we found less number of summer days, in open midrise areas about 90-100 days, open low-rise areas 70-80 days. In rural areas there was only 60-70 days.

The time period 1971-2000 is the standard reference time for climate models. Fig. 5 shows the map for this period calculated using the climate data from climate models. It has almost similar spatial pattern to the one of 1981-2010. In the city center, there are the highest values (about 90-100 days), in open midrise areas about 80-90 days, in open low-rise areas 70-80 days, and in rural areas only 60-70 days.

In case of Vienna, the reference simulation shows a typical spatial distribution with the maximum heat load in densely built-up areas in the city center and in residential areas in the flat terrain northeast of the river Danube (Fig. 6). Both orography and land use distribution influence the thermal characteristics. Due to the orography and prevailing winds from the northwest and southeast, the heat load in the residential areas located on the hill slopes in the west is lower than the heat load in the same type of built-up in the flat terrain located southward and eastward of the city center. The spatial pattern in the simulations for the periods 1971-2000 and 1981-2010, based on the measured data, is similar. However, the more recent climate period indicates a warming trend, which is found in observational time series. The simulation for the time period 1971-2000 based on climate model data is similar to the simulation based on the observational data for the same time period. The simulation based on the climate model data is further use as the reference for evaluation of future climate changes.

Fig. 7 presents distribution of summer days in Brno as simulated with MUKLIMO model for recent climate. Spatial distribution of this variable reflects well the role of the main natural and anthropogenic factors that form urban climate. In case of Brno area, those are mainly altitude and land cover type. Under recent 
climate conditions, the number of summer days varies from 20-30 in northern and western parts in higher elevations to more than 100 in the city center. Spatial distribution of summer days within the Brno cadastral correlate well with density of buildings. The highest values are typical for the city center, but also for the Brno exhibition area (located south-east from the center) and also for relatively large areas of former factories (north-west of city center). Three maps on Fig. 7 for three successive 30-year long periods also well document gradual rising of air temperatures in this area. This increasing trend is statistically significant especially for summer months and on average it reaches $0.5^{\circ} \mathrm{C} / 10$ years in the period $1961-$ 2010 .

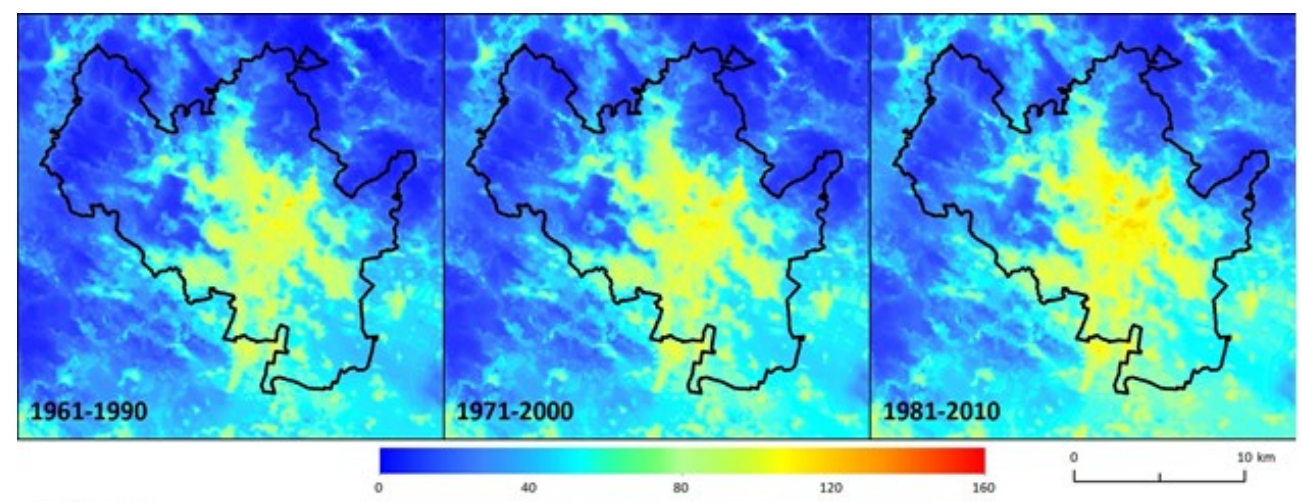

Fig. 7 Mean annual number of summer days simulated using the data of the climate models in Brno for in three different reference periods (1961-1990, 1971-2000, 1981-2010)
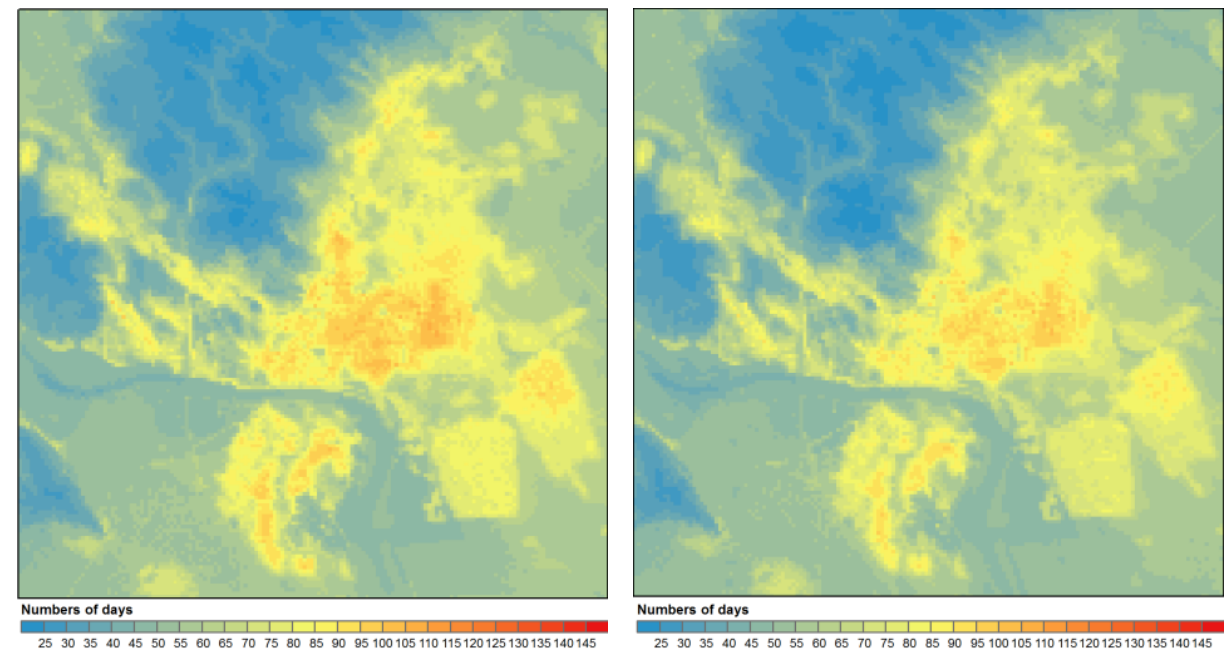

Fig. 8 Mean annual number of summer days in Bratislava in the period 1981-2010 using the measured data (left) and in the period 1971-2000 using the data of the climate models (right)

In Bratislava, reference simulation also shows a considerable influence of terrain, as there is an evident connection between lower heat load and higher altitude, while there are also clearly defined most compact built-up urbanized areas. There is an obvious spatial 
distribution of highest number of summer days with higher values in most compact urban areas in the center, as well as in residential districts to the south and industrial to the east. The spatial pattern also clearly shows the impact of the mountain range and forested areas in the north and west with the lowest observed values. The simulations for the periods 19712000 and 1981-2010 (Fig. 8) share a similar spatial pattern, but there are slightly higher values in case of 1981-2010 period related to the warming in recent years and partly due to the different form of input (climate model vs. real station measurements). Difference between simulation of 1971-2000 based on climate model data and 1981-2010 based on real observation however is not overly significant. For both simulations the highest values are in the range of about 100-110 days, and the lowest at only 20-30 days.

In Kraków, the data for the reference period 1971-2000 show that in the most densely urbanized areas, mean annual number of summer days was about 60 days (in 1981-2010: about 66) while e.g. in forested areas located within the city borders the number was below 5 days (1981-2010: 5.6; Fig. 9). Large differences are also seen in rural areas between valleys and hilltops nearby; the values for the valleys were significantly larger. As suburban areas tend to develop intensively, relatively large values of the number of summer days can be also observed in areas surrounding the city, especially in small cities like Wieliczka or Skawina. The area of the Vistula river bottom is rather diversified in terms of the index discussed, as there are the most urbanized areas located, together with large areas of urban green and water areas.
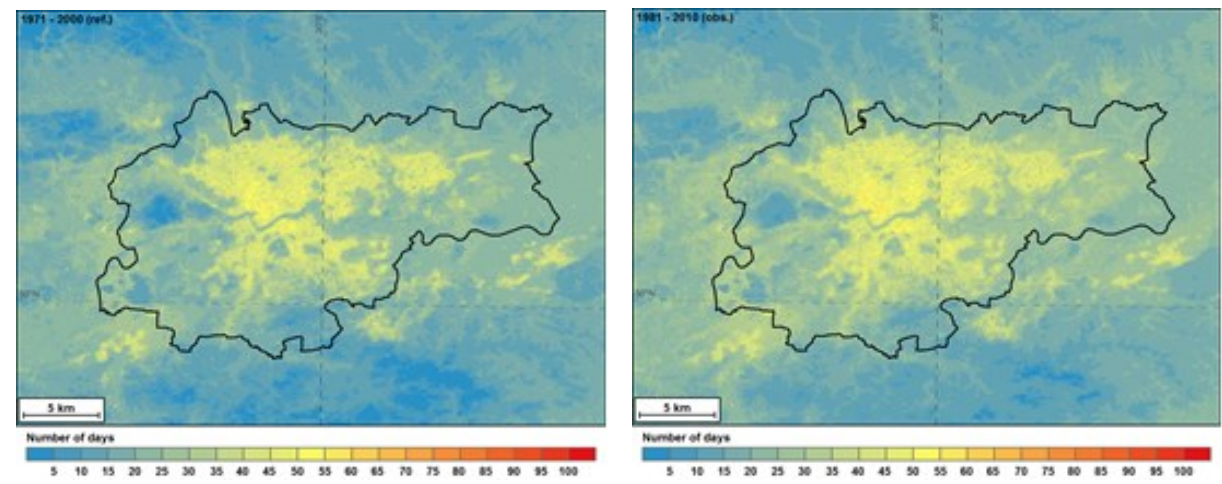

Fig. 9 Mean annual number of summer days in Kraków in the period 1971-2000 using the data of the climate models (left) and in the period 1981-2010 using the observations (right)

\subsection{Validation}

In Szeged, for the validation, we compared the data from the map of summer days, from the points located closest to the two meteorological stations in Szeged, with the data available from those stations. The data from the rural station is a mean value for 1981-2010, in urban station is a mean value for 1999-2010. In rural station the model resulted 54 summer days and based on the measurements there was 89 days. For the urban site the values are more similar, based on the measurements there is 94 days and the model gives 108 days.

In case of Vienna, the model results for the time period 1981-2010 are compared to 7 monitoring stations which have more than 10 years of measurements. The model results for the urban station Vienna Innere Stadt agree well with the observations. Mean annual number of summer days in the model is 79.4 , while observed value is 72.3 summer days in average 
for the period 1985-2010. At the rural station Groß Enzersdorf, an average of 65.7 summer days is observed. The model results yield a value of 56.8 summer days, which underestimates the measured value by $14 \%$. However, the comparison between stations in different environment shows variable model performance. The best agreement is found for the station Vienna Hohe Warte $(-5 \%)$ located in residential areas in northwestern part of the city. In comparison with the station Groß Enzersdorf, the results

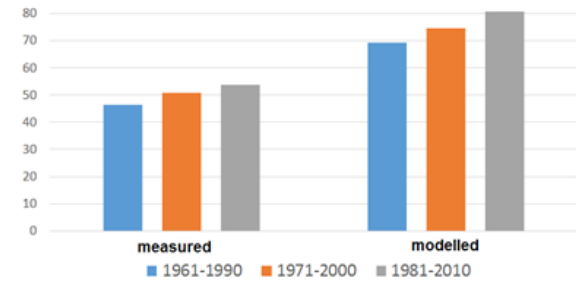

Fig. 10 Mean numbers of summer days as measured (left) and simulated with the MUKLIMO 3D model (right) in Brno area for three different periods representing recent climate for the airport station Schwechat representative for the rural environment as well, show a slight overestimation (68.5 summer days in the model compared to the 62.8 summer days in monitoring records). The reason for variable model performance could be the simplified land use distribution when using LCZ classification, which might not be representative for different micro-environments in Vienna.

In case of Brno, direct validation of simulated number of summer days can be done only for Brno, Turany station (Fig. 10). This station is located at the Brno airport in southeast part of the cadastral area and unfortunately, this station is neither typical urban nor typical rural station. From Fig. 10 it follows that model MUKLIMO 3D in general overestimates the number of summer days and this overestimation is about $50-60 \%$. However, it must be stressed that this type of validation that is based on only one station may be biased or not well representative, because the found difference may be influenced due to many factors, e.g. proper classification of LCZ in this area.

For the city of Bratislava, the model in selected rural location within the modeled region shows on average 56 summer days for 1981-2010 period, while according to the measurements at respective rural station the mean annual number of summer day was 69 summer days. As for urban location (within the airport area) the model states that there was on average 72 summer days during year and according to the measurements at local station in 1981-2010 period the mean annual number of summer days was 54. In both rural and urban locations the mean annual number of summer days for 1981-2010 period presented by model, was therefore lower than values provided by station measurements.

In case of Kraków, data from the two stations mentioned in table 3 (Balice airport, rural station and Botanical Garden, urban station) were used for comparison with the data generated with the model. The data presented in Table 7 show that the model shows lower values than measured, as already mentioned for other cities. However, the tendencies of changes are predicted correctly; the measurements show that the difference in the number of summer days between the urban and rural station decreased from 12.1 days (1971-2000) to 10.2 days (1981-2010) and the modelled values are 15.3 and 14.3 days.

Table 7 Mean annual number of summer days at the rural (Balice airport) and urban (Botanical Garden) stations in Kraków, according to measurements and modelled values

\begin{tabular}{lrrrr}
\hline \multirow{2}{*}{ Period } & \multicolumn{2}{c}{ 1971-2000 } & \multicolumn{2}{c}{ 1981-2010 } \\
Station & measured & modelled & measured & modelled \\
\hline Balice airport & 38.1 & 28.6 & 46.2 & 31.3 \\
Botanical Garden & 50.2 & 43.9 & 56.4 & 45.6 \\
\hline
\end{tabular}


Bokwa A, Dobrovolný P, Gál T, Geletič J, Gulyás Á, Hajto MJ, Holec J, Hollósi B, Kielar R, Lehnert M, Skarbit N, Štastný P, Švec M, Unger J, Walawender JP, Žuvela-Aloise $M$

\subsection{Future scenarios}

In this section, the predictions of heat load changes in 2021-2050 and 2071-2100 are presented. First the data for each city is analyzed and then an attempt of comparative analysis of all the cities is undertaken.

In Szeged, in the period 2021-2050, the number of summer days is supposed to increase compared to the present conditions. The spatial pattern is supposed to remain unchanged. The highest number of summer days is expected to be found in the city center. However, in case of RCP2.6 and RCP4.5, the number of summer days in the city centre is supposed to reach about 120 days, while in case of RCP8.5 it is 130 days (Fig. 11).

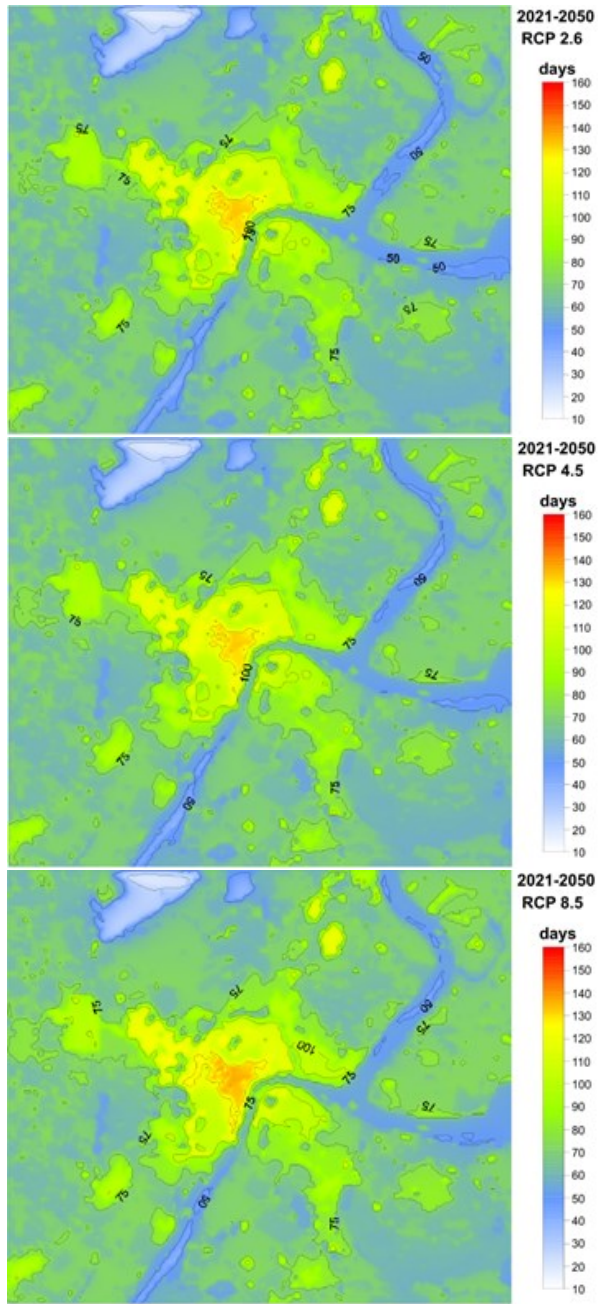

Fig. 11 Mean annual number of summer days in Szeged in the period 2021-2050 using the model simulations for the RCP2.6 (top) RCP4.5 (center) and RCP 8.5 (bottom) scenarios

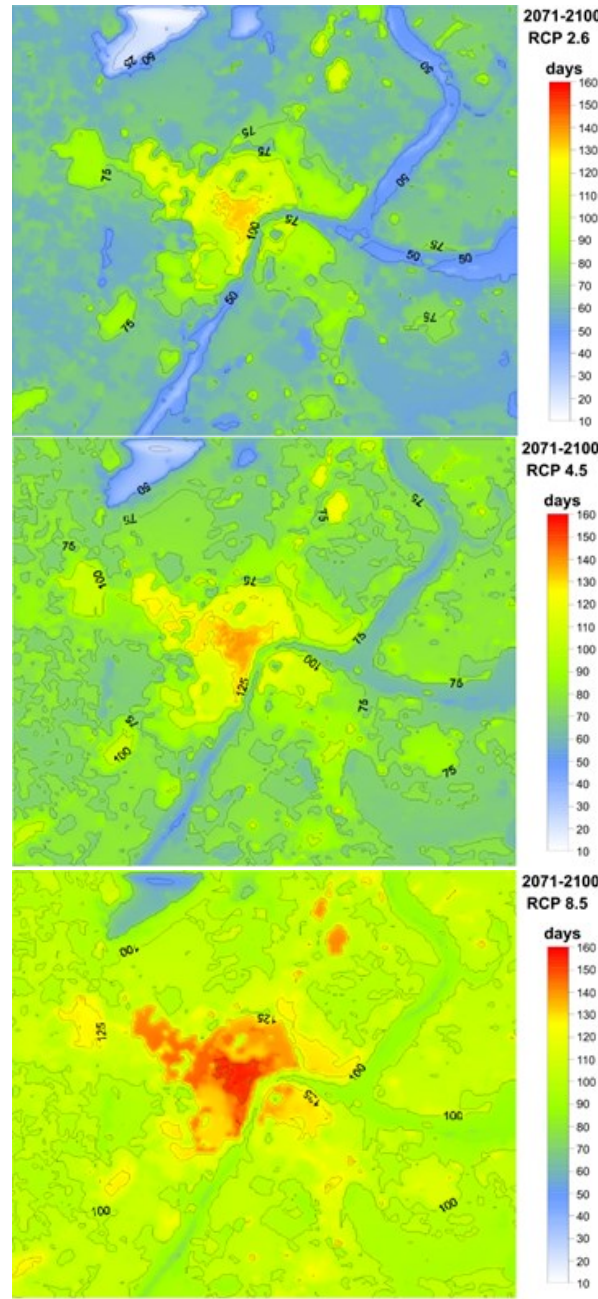

Fig. 12 Mean annual number of summer days in Szeged in the period 2071-2100 using the model simulations for the RCP2.6 (top) RCP4.5 (center) and RCP8.5 (bottom) scenarios 

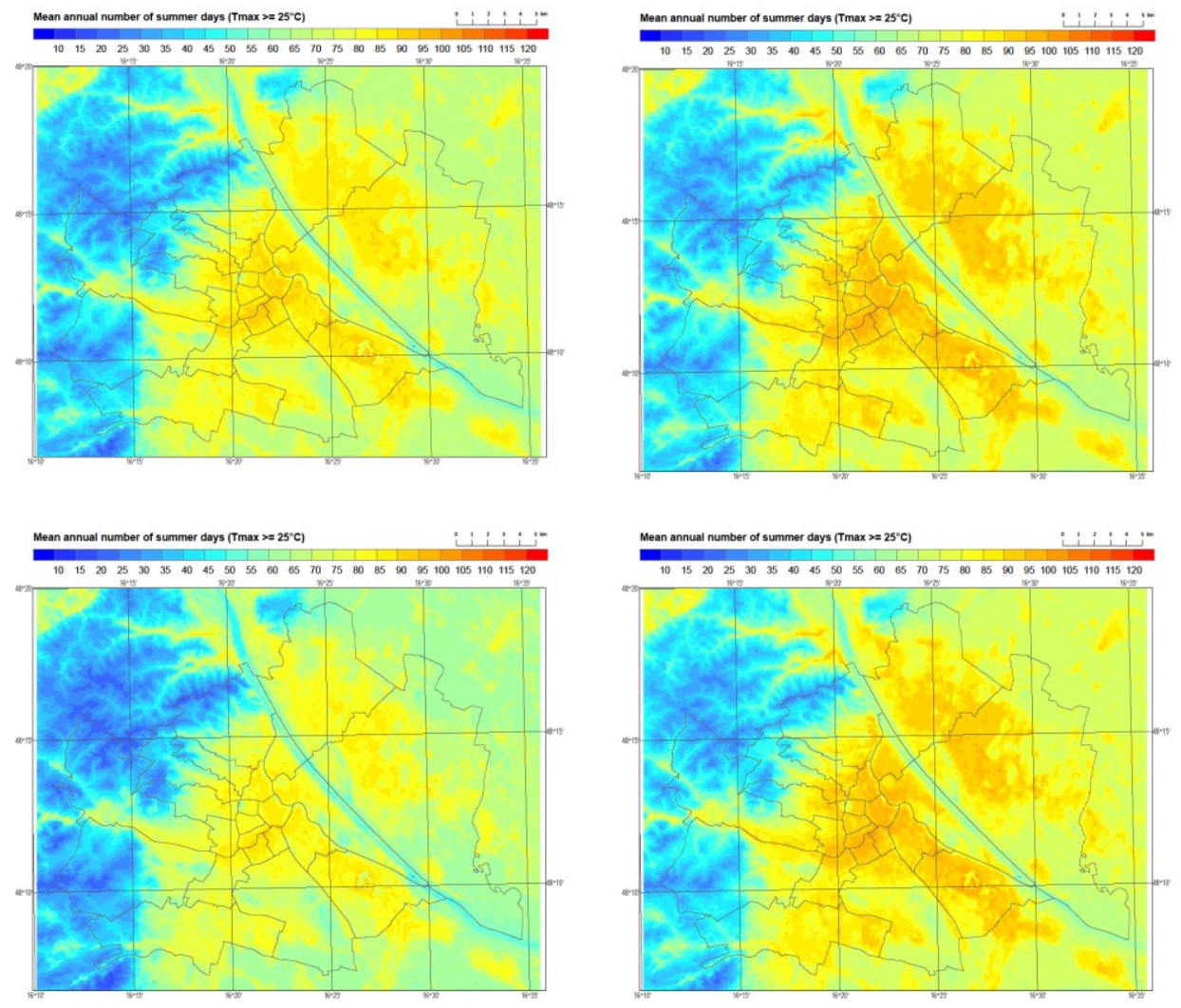

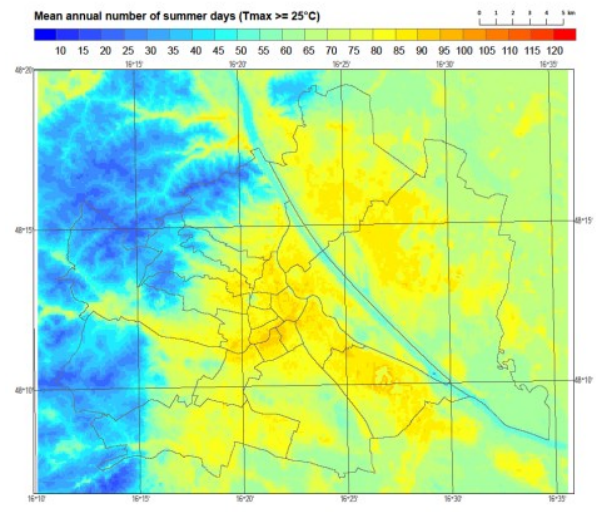

Fig. 13 Mean annual number of summer days in Vienna in the period 2021-2050 using the model simulations for the RCP2.6 (top) RCP4.5 (center) and RCP8.5 (bottom) scenarios

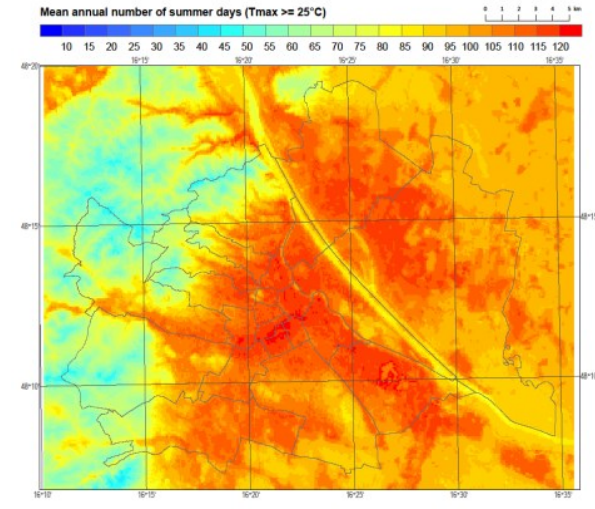

Fig. 14 Mean annual number of summer days in Vienna in the period 2071-2100 using the model simulations for the RCP2.6 (top) RCP4.5 (center) and RCP8.5 (bottom) scenarios 


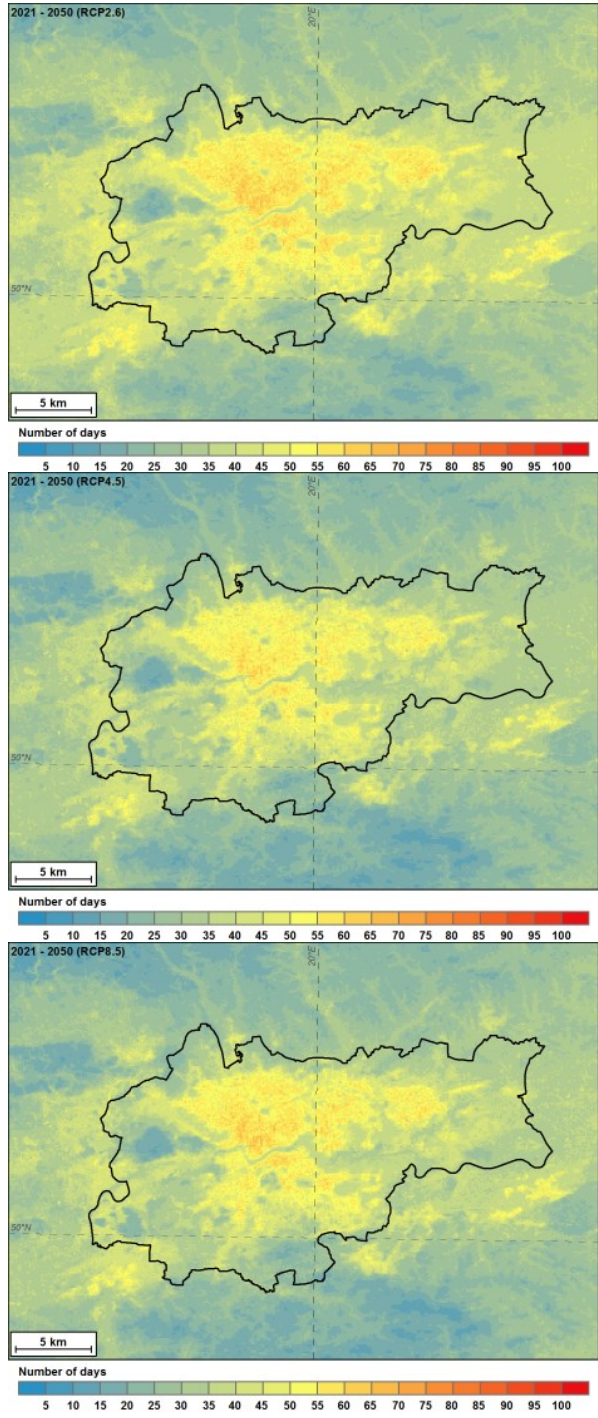

Fig. 15 Mean annual number of summer days in Kraków in the period 2021-2050 using the model simulations for the RCP2.6 (top), RCP4.5 (center) and RCP8.5 (bottom) scenarios

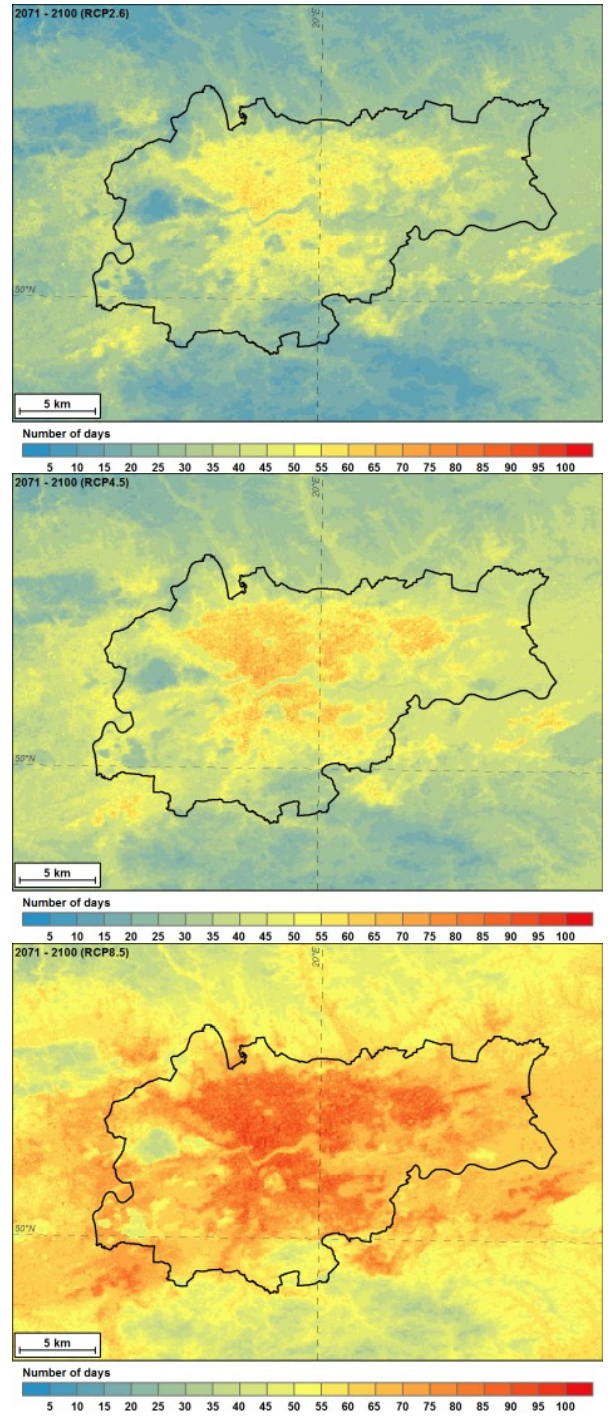

Fig. 16 Mean annual number of summer days in Kraków in the period 2071-2100 using the model simulations for the RCP2.6 (top), RCP4.5 (center) and RCP8.5 (bottom) scenarios

For the end of the century (2071-2100) the number of summer days is significantly different in different RCPs. The spatial patterns are basically similar in each case, because the urban effects are similar, i.e. it is assumed in the present analysis that the land use/land cover remains unchanged. In the case of RCP2.6 (Fig. 12) there is no change compared to 2021-2050 (Fig. 11). RCP4.5 represents a moderate change in the number of summer days, 
the highest values are around 140 days. RCP8.5 is the worst scenario and the results differ significantly from the other scenarios and time periods, because the highest values are around 160 days (Fig. 12) and even in the rural areas the numbers of summer days are higher than the numbers of summer days in the urban areas in the present climate conditions (Figs. 4, 5).
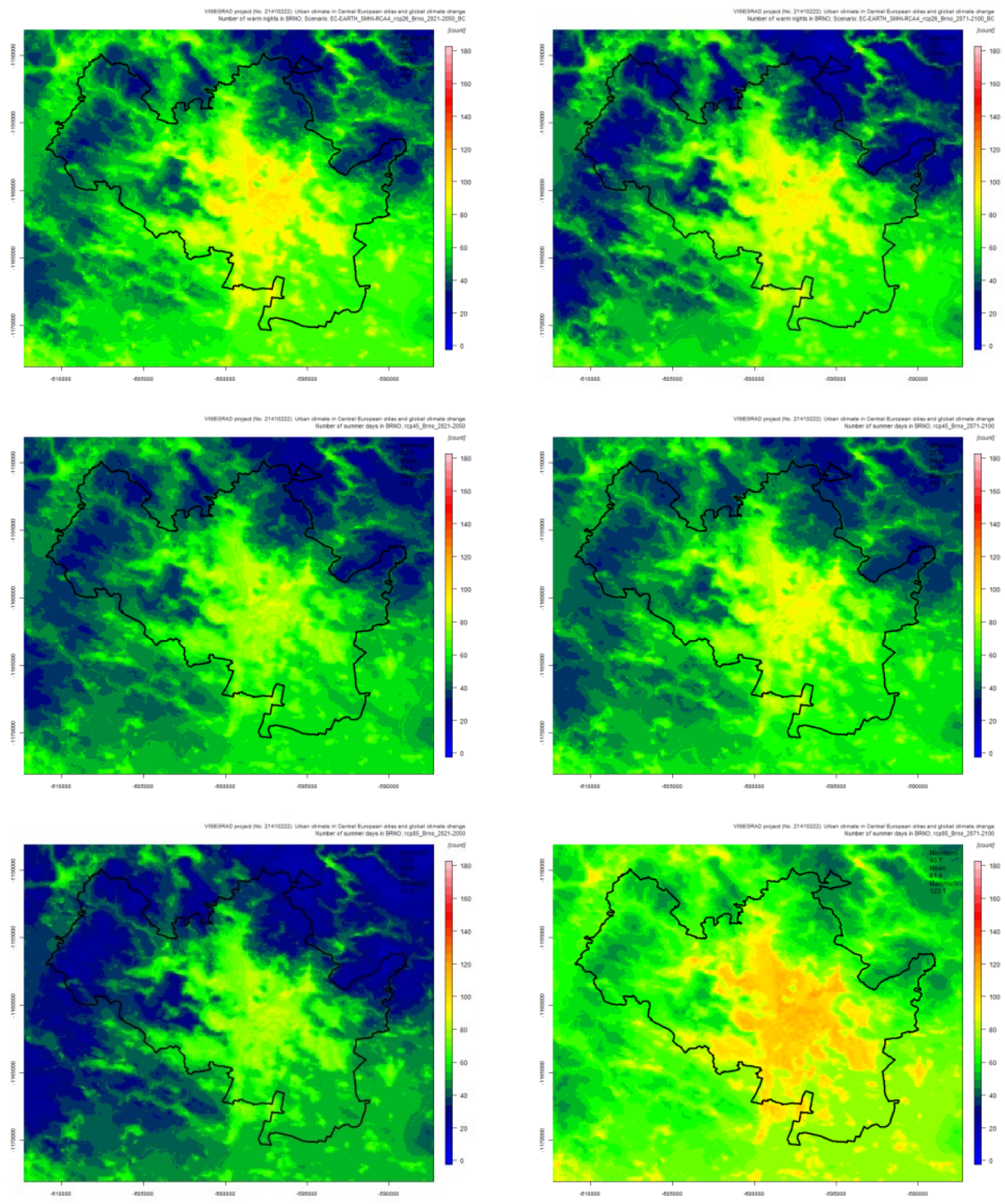

Fig. 17 Mean annual number of summer days in Brno in the period 2021-2050 using the model simulations for the RCP2.6 (top), RCP4.5 (center) and RCP8.5 (bottom) scenarios

Fig. 18 Mean annual number of summer days in Brno in the period 2071-2100 using the model simulations for the RCP2.6 (top), RCP4.5 (center) and RCP8.5 (bottom) scenarios 
In case of Vienna, the model results for the time period 2021-2050 show moderate increase in the number of summer days compared to the reference simulation (Fig. 13). The intensity of warming and the spatial pattern do not vary much between different climate scenarios. For the end of the century (2071-2100) the increase in number of summer days is substantially different for each RCP scenario (Fig. 14). Minimal change is found for the RCP2.6 compared to the 2021-2050 simulation. The RCP4.5 indicates an intermediate change, while the RCP8.5 scenarios shows extreme increase in the number of summer days. The highest values are around 120 days compared to about 70 days found in the reference simulation.

In Kraków, for the period 2021-2050, all scenarios show a slight increase in the mean annual number of summer days; the mean value for the whole domain is expected to increase by about 10 days and reach the value of about 30 days (Fig. 15). In case of the period 20712100 (Fig. 16), the uncertainty of predictions increases, and mean values vary depending on the scenario chosen from 30 to 65 days. For both periods considered, the spatial pattern shows the impact of both land use/land cover and relief on the thermal conditions. The highest numbers of summer days can be found in densely built-up areas, located in the valley floor, and in urban areas located close to Kraków borders. The lowest values are observed for forested areas. Additionally, in rural areas surrounding Kraków, larger numbers of summer days can be found in the valleys than at the hilltops nearby. Green urban areas located between strongly urbanized parts of the city show smaller number of summer days than builtup areas.

In case of Brno, the model results for the middle of this century (2021-2050) show about $40 \%$ increase in the number of summer days compared to the reference simulation for RCP4.5, RCP8.5 scenarios (Fig. 17). Distinctly higher number of summer days show RCP2.6 scenario (increase about $60 \%$ compared to recent climate). This difference, however, is related to the fact that lower number of regional model outputs was used for RCP2.6 scenario. Simulated numbers of summer days are compared to the reference Brno, Turany station. Thus there is and an increase from about 37 days (1971-2000) to 52 days (2021-2050) in case of scenarios RCP4.5 and RCP8.5 and 57 days (2021-2050) in case of RCP2.6. Quite different results as for individual scenarios were found for the Brno climate simulations of the end of the 21 century (2071-2100) - see Fig. 18. While RCP2.6 scenario predicts on average 52 summer days in Brno area, RCP4.5 scenario predicts slightly higher - 59 summer days (that is $60 \%$ increase compared to the present). Significantly higher number of summer days can be seen for the RCP8.5 scenario; 81 summer days represents $120 \%$ of the present value.

In case of Bratislava, there is a moderate increase in the number of summer days in the study area for the time period 2021-2050 compared to the reference simulation (Fig. 19). The scenarios show that mean number of days for the whole region would increase by around 20 days. The maximum number of summer days in 2021-2050 period for the worst RCP8.5 scenario could be 130 days, which is about 26 more summer days annually compared to the reference simulation of 1971-2000. In the later 2071-2100 period the average and maximum number of summer days within the modeled region as well as their spatial distribution have greater variance depending on the input scenario (Fig. 20). Mean values in this period calculated for the whole region vary depending on the scenario from 78 to 119 days. The model yields a maximum value of 148 summer days for RCP8.5 scenario compared to about 100 days found in the reference simulation. 

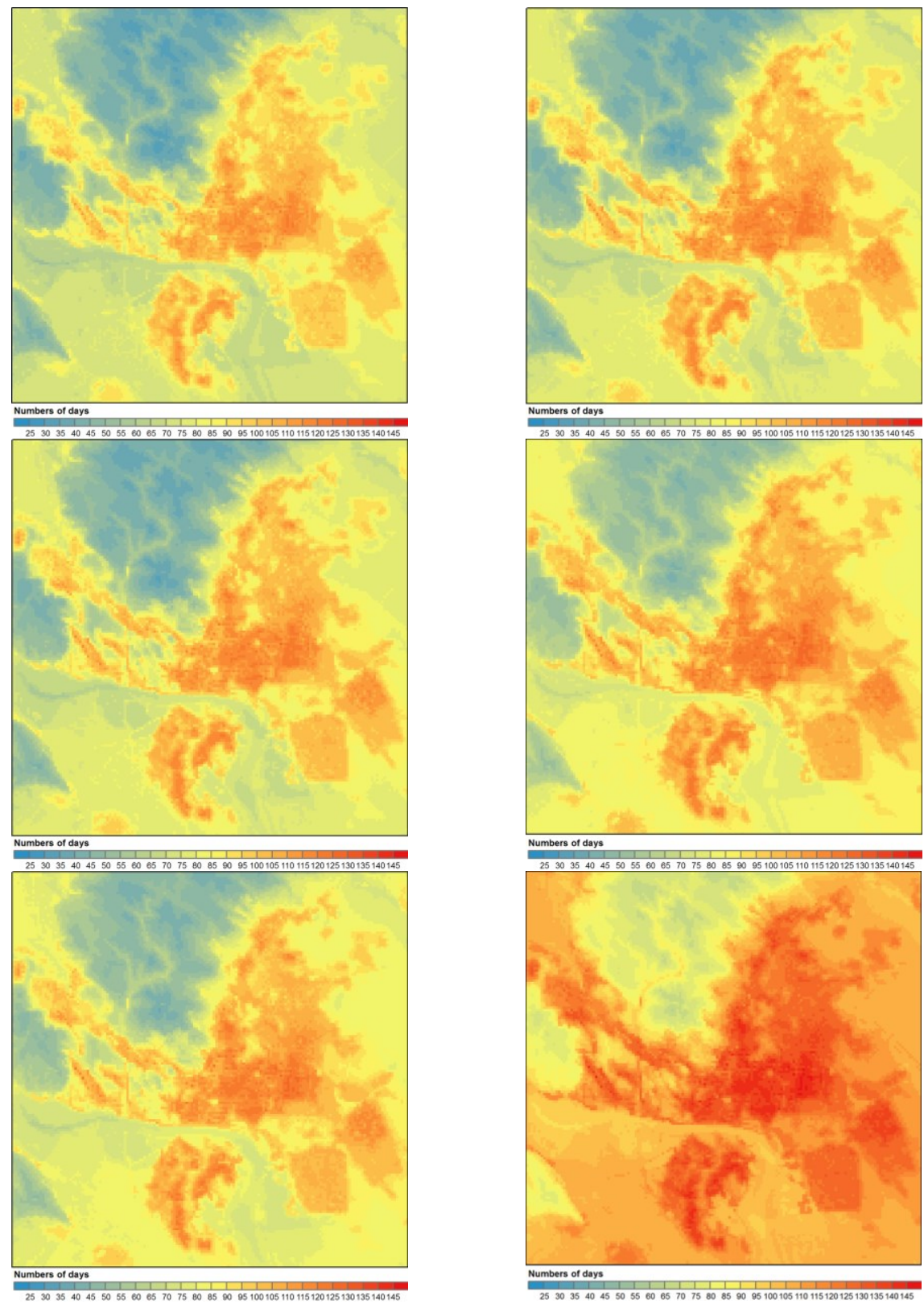

Fig. 19 Mean annual number of summer days in Bratislava in the period 2021-2050 using the model simulations for the RCP2.6 (top), RCP4.5 (center) and RCP8.5 (bottom) scenarios

Fig. 20 Mean annual number of summer days in Bratislava in the period 2071-2100 using the model simulations for the RCP2.6 (top), RCP4.5 (center) and RCP8.5 (bottom) scenarios 
Bokwa A, Dobrovolný P, Gál T, Geletič J, Gulyás Á, Hajto MJ, Holec J, Hollósi B, Kielar R, Lehnert M, Skarbit N, Štastný P, Švec M, Unger J, Walawender JP, Žuvela-Aloise $M$

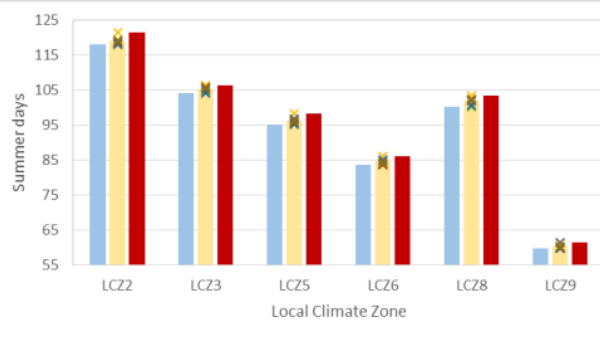

= Min. $=$ Mean $=$ Max. $\times$ CNRM $\times$ DMI $\times$ KNMI $\times$ SMHI $\times$ Hadgem $\times$ IPSL $\times$ MPI

Fig. 21 Maximum, mean and minimum of mean annual number of summer days in Szeged in the period 1971-2000 using the applied climate models in different LCZ classes

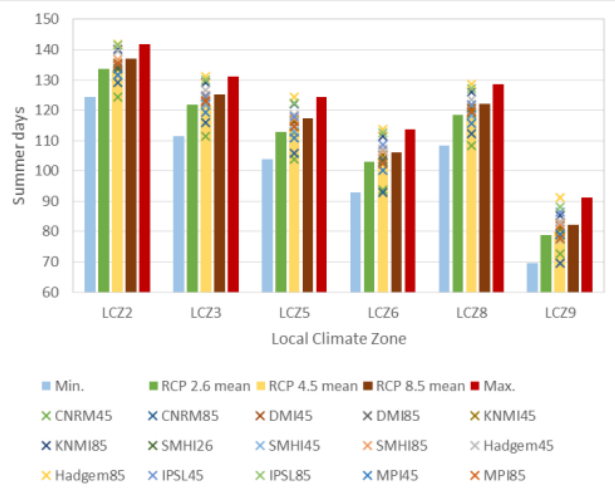

Fig. 22 Maximum, mean of the different RCPs and minimum of mean annual number of summer days in the period 2021-2050 using the applied climate models in different LCZ classes in Szeged

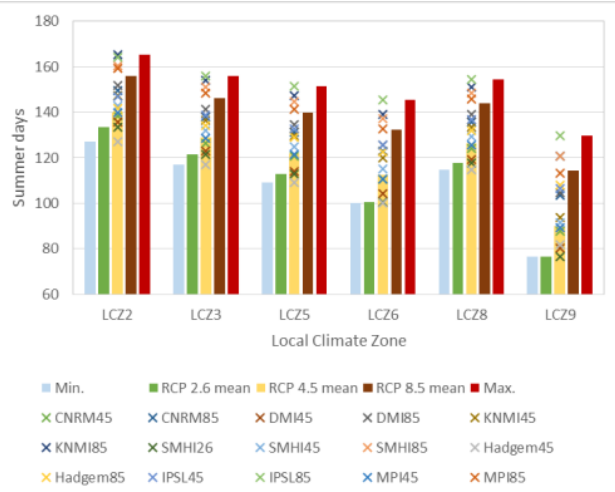

Fig. 23 Maximum, mean of the different RCPs and minimum of mean annual number of summer days in the period 2071-2100 using the applied climate models in different LCZ classes in Szeged

\subsection{Changes of heat load in land use types}

In order to analyze the heat load change in connection with land use/land cover, the following procedure was used. One or a few points were found for each LCZ in each city.

Those were the points in the centers of the largest homogenous LCZ areas of the city. For those points, maximum, minimum and mean values of mean annual number of summer days were compared, using data from the EURO-CORDEX climate models (see section 4.3) downscaled with cuboid method (see section 4.1). The procedure allows to compare the absolute or relative ( $\%$ change) values of the cities for different 30 -year periods. The procedure is shown using the example of Szeged and Brno.

In Szeged, the intra urban difference is significant in the present climate conditions, LCZ9 (sparsely built) and LCZ6 (open low-rise) have less summer days. LCZ2 (compact mid-rise) has two times more summer days than LCZ9 (Fig. 21).

The intra urban differences remain the same in the period 2021-2050 (Fig. 22) or 2071-2100 (Fig. 23). In the period 20212050 , the minimum predicted number of summer days occur in LCZ9 and the maximum in LCZ2. Difference between models is almost the same as the difference between LCZs except LCZ9. In period 2071-2100 the thresholds of the different models are increasing.

Relative values were calculated for the minimum, maximum and mean of model results for particular LCZ type. In case of RCP2.6, 4.5 and 8.5 the reference value was the model mean for 1971-2000. The results show that the highest increase is predicted in LCZ9 or LCZ6 (Figs. 24, 25). Those are the areas with less dense built-up than the city centre, so the increase in built-up area share in those parts of the city can cause serious hazards for the inhabitants, due to the increase of the heat load. The differences in 
relative change (Figs. 24, 25) are not enough to distinguish the differences in the number of the summer days between LCZs (Figs. 22, 23).

Similar analysis was performed for Brno and the results are shown in Figs. 26-30. In 1971-2000, the highest mean values were observed for LCZ2 (compact mid-rise) and LCZ 8 (large low-rise). The highest increase is predicted in LCZ9, like in the case of Szeged.

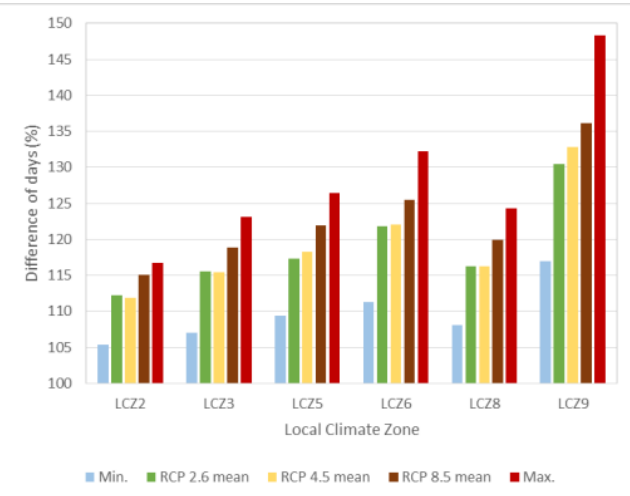

Fig. 24 Change of maximum, mean of the different RCPs and minimum of mean annual number of summer days in the period 2021-2050 using the applied climate models in different LCZ classes compared to 1971-2000 (min., mean and max., respectively) in Szeged

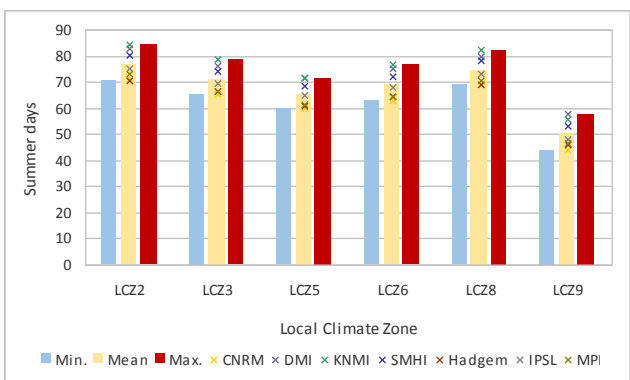

Fig. 26 Maximum, mean and minmum of mean annual number of summer days in Brno in the period 1971-2000 using the applied climate models in different LCZ classes

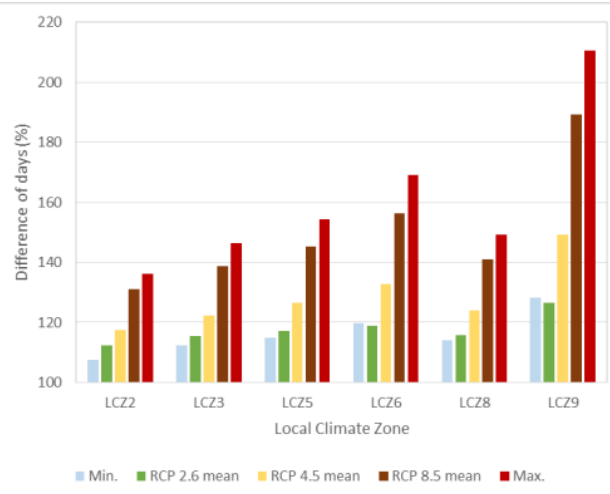

Fig. 25 Change of maximum, mean of the diffrent RCPs and minmum of mean annual number of summer days in the period 2071-2100 using the applied climate models in different LCZ classes compared to 1971-2000 (min., mean and max., respectively) in Szeged

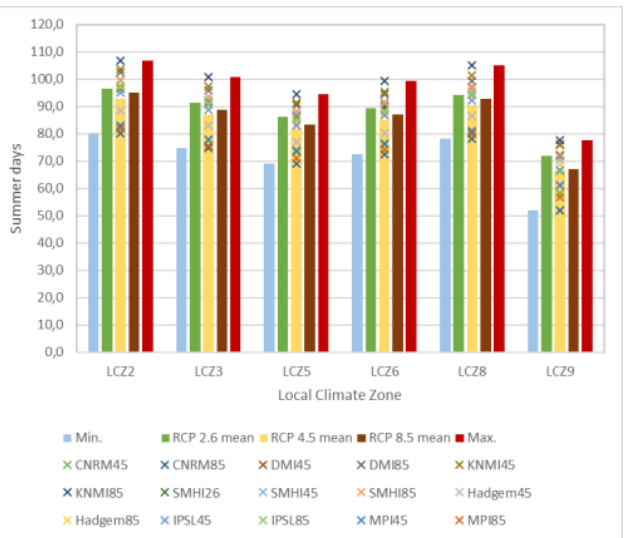

Fig. 27 Maximum, mean of the different RCPs and minimum of mean annual number of summer days in the period 2021-2050 using the applied climate models in different LCZ classes in Brno 


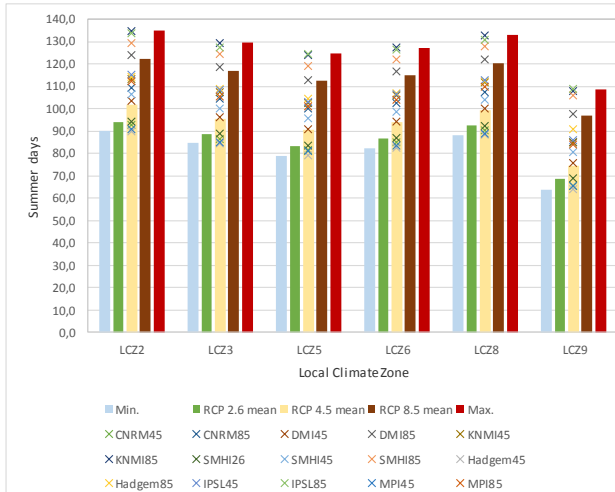

Fig. 28 Maximum, mean of the different RCPs and minimum of mean annual number of summer days in the period 2071-2100 using the applied climate models in different LCZ classes in Brno

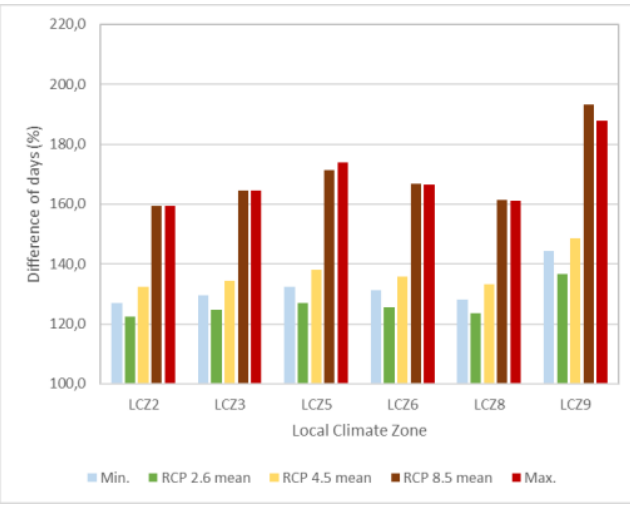

Fig. 30 Change of maximum, mean of the different RCPs and minimum of mean annual number of summer days in the period 2071-2100 using the applied climate models in different LCZ classes compared to 1971-2000 (min., mean and max., respectively) in Brno

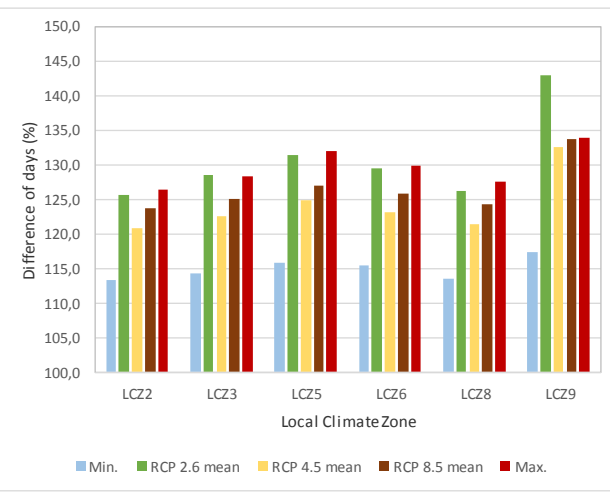

Fig. 29 Change of maximum, mean of the different RCPs and minimum of mean annual number of summer days in the period 2021-2050 using the applied climate models in different LCZ classes compared to 1971-2000 (min., mean and max., respectively) in Brno

\section{DISCUSSION}

The results obtained for particular cities can be compared in order to formulate the features characteristic for the cities in the whole region of Central Europe. The predictions for the period 2021-2050 show a rather slight increase in the mean annual number of summer days, while for the period 2071-2100, the predicted values are much larger. The scenario RCP2.6 is the most optimistic one in terms of future $\mathrm{CO}_{2}$ concentration and impact, but unfortunately the chances that it will be realized are rather modest. Therefore, the predictions for the period 2071-2100, for the scenarios RCP4.5 and RCP8.5 were analyzed further. Tables 8 , 9 and 10 present the characteristic values for each city and scenario, in relation to the reference period 1971-2000. The values in Table 8 refer to the results shown in Figs. 11-20.

Table 8 shows large differences among the cities in the mean number of summer days in the reference period 1971-2000 (mean values for the whole domains). Cities located in the southern part of Central Europe (represented by Szeged) have on average twice as much summer days than cities located north of the Carpathian Mts. (represented by Kraków). It is a result of climatic variability of Central Europe, linked to the transitional character of all elements of the natural environment. The Carpathian Mts. constitute a significant climatic barrier. South of that mountain chain, the impact of the Mediterranean Sea is one of the factors controlling climatic conditions while north of the Carpathians, polar air masses 
(maritime from the west and continental from the east) decide about large weather variability and more severe climatic conditions.

Table 8 Mean annual number of summer days, 1971-2000 and 2071-2100 (RCP4.5 and RCP8.5)

\begin{tabular}{|c|c|c|c|c|c|c|c|c|c|}
\hline \multirow{3}{*}{ City } & \multicolumn{3}{|c|}{ Mean } & \multicolumn{3}{|c|}{ Min } & \multicolumn{3}{|c|}{$\operatorname{Max}$} \\
\hline & \multirow{2}{*}{$\begin{array}{c}1971- \\
2000\end{array}$} & \multicolumn{2}{|c|}{ 2071-2100 } & \multirow{2}{*}{$\begin{array}{c}1971- \\
2000\end{array}$} & \multicolumn{2}{|c|}{ 2071-2100 } & \multirow{2}{*}{$\begin{array}{c}1971- \\
2000\end{array}$} & \multicolumn{2}{|c|}{ 2071-2100 } \\
\hline & & RCP4.5 & RCP8.5 & & RCP4.5 & RCP8.5 & & RCP4.5 & RCP8.5 \\
\hline Kraków & 20.3 & 37.8 & 59.2 & 4.0 & 14.8 & 28.7 & 61.1 & 78.6 & 100.3 \\
\hline Brno & 37.2 & 59.3 & 81.4 & 10.5 & 27.4 & 40.7 & 83.4 & 102.1 & 123.1 \\
\hline Vienna & 45.4 & 70.0 & 93.4 & 7.2 & 21.3 & 40.0 & 82.8 & 107.8 & 128.8 \\
\hline Bratislava & 56.4 & 85.9 & 107.8 & 20.6 & 42.4 & 65.0 & 104.1 & 131.2 & 148.9 \\
\hline Szeged & 50.1 & 79.1 & 104.3 & 7.8 & 24.3 & 78.5 & 123.4 & 142.8 & 159.1 \\
\hline
\end{tabular}

Explanations: mean - mean value for the whole domain of a certain city (see Fig. 1), min - the lowest value found in a domain, max - the highest value found in the domain

Additionally, data from Table 8 show that the difference in mean annual number of days (mean values for the whole domain) between Szeged and Kraków might increase in the future: for 1971-2000 it was about 30 days, while for 2071-2100 it is predicted to increase up to about 41-45 days, depending on the scenario. Minimum and maximum values shown in table 8 are much more dependent on local land use/land cover variability than on general climatic conditions; those values represent areas in each city where extremely low or high values can occur. But those values also show the range of the values that can be experienced in each city. For the reference period, the largest difference was noted for Szeged (about 166 days) while the smallest for Kraków (57 days). In all cities, maximum and minimum values are predicted to increase, but the changes in the range of the values (i.e. the difference between the maximum and minimum value) shows no uniform tendency. In Kraków, Brno and Vienna the range is predicted to increase in comparison to 1971-2000 (by 2-15 days, depending on the scenario used), in Bratislava it is predicted to be almost unchanged, and in Szeged - it might decrease even by 35 days. The decrease for Szeged might constitute a particular hazard for the inhabitants.

Tables 9 and 10 show the absolute and relative changes of the values shown in Table 8. Relative values (in \%) in table 10 show a larger increase in mean values for the whole domain in the north of the region (Kraków and Brno: 192 and 119\% for RCP8.5) than in the south (Szeged: 108\% for RCP8.5). An interesting feature is the difference in most values between Vienna and Bratislava, as they are located so close to each other. On one hand, Bratislava is a much smaller city than Vienna, so the impact of built-up area on urban climate is smaller, too. On the other hand, each city is located in different environmental conditions, including relief, which is a significant element controlling urban climate. From all the cities considered, Szeged is the only one located in a flat area and it is also the smallest city comparing to the others. Even though the absolute number of summer days (mean for the whole domain) is predicted to be the highest there in 2071-2100, the relative increase is comparable to Vienna or Brno, while for Kraków the values of relative increase are the highest. The indices discussed above allow to see the regional dimension of the predicted heat load increase. The local dimension can be discussed for each city in terms e.g. of the spatial planning. As mentioned in the introduction section, all cities studied except Szeged are located in a complicated relief conditions. The figures presented in section 3 show that concave land forms (e.g. valley bottoms) experience larger numbers of summer days than nearby hilltops. It is a phenomenon well known from the studies on the climate of the mountains. Even though the cities considered are not located in the mountains, the differences 
Bokwa A, Dobrovolný P, Gál T, Geletič J, Gulyás Á, Hajto MJ, Holec J, Hollósi B, Kielar R, Lehnert M, Skarbit N, Štastný P, Švec M, Unger J, Walawender JP, Žuvela-Aloise $M$

in relative altitude are large enough to contribute to the generation of the processes known from mountainous areas (e.g. katabatic flows, air temperature inversions). However, those processes can be observed mainly during the night time, while the present study concerns the daytime and the occurrence of the maximum temperature $\geq 25^{\circ} \mathrm{C}$. During the day time, there are no such large differences in air temperature between valleys and hilltops as during the night but valley floors tend to have higher maximum air temperature and that is also visible in the data presented above.

Table 9 Increase (in number of days) of mean annual number of summer days in the periods 19712000 and 2071-2100 (RCP4.5 and RCP8.5)

\begin{tabular}{|c|c|c|c|c|c|c|c|c|c|}
\hline \multirow{3}{*}{ City } & \multicolumn{3}{|c|}{ Mean } & \multicolumn{3}{|c|}{ Min } & \multicolumn{3}{|c|}{ Max } \\
\hline & \multirow{2}{*}{$\begin{array}{c}1971- \\
2000\end{array}$} & \multicolumn{2}{|c|}{ 2071-2100 } & \multirow{2}{*}{$\begin{array}{c}1971- \\
2000\end{array}$} & \multicolumn{2}{|c|}{ 2071-2100 } & \multirow{2}{*}{$\begin{array}{c}1971- \\
2000\end{array}$} & \multicolumn{2}{|c|}{ 2071-2100 } \\
\hline & & RCP4.5 & RCP8.5 & & RCP4.5 & RCP8.5 & & RCP4.5 & RCP8.5 \\
\hline Kraków & 20.3 & 17.5 & 38.9 & 4.0 & 10.8 & 24.7 & 61.1 & 17.5 & 39.2 \\
\hline Brno & 37.2 & 22.1 & 44.2 & 10.5 & 16.9 & 30.2 & 83.4 & 18.7 & 39.7 \\
\hline Vienna & 45.4 & 24.6 & 48.0 & 7.2 & 14.1 & 32.8 & 82.8 & 25 & 46 \\
\hline Bratislava & 56.4 & 29.5 & 51.4 & 20.6 & 21.8 & 44.4 & 104.1 & 27.1 & 44.8 \\
\hline Szeged & 50.1 & 29.0 & 54.2 & 7.8 & 16.5 & 70.7 & 123.4 & 19.4 & 35.7 \\
\hline
\end{tabular}

Explanations: mean - mean value for the whole domain of a certain city (see Fig. 1), min - the lowest value found in a domain, max - the highest value found in the domain

Table 10 Increase (in \%) of mean annual number of summer days, in the periods 1971-2000 and 2071-2100 (RCP4.5 and RCP8.5)

\begin{tabular}{|c|c|c|c|c|c|c|c|c|c|}
\hline \multirow{3}{*}{ City } & \multicolumn{3}{|c|}{ Mean } & \multicolumn{3}{|c|}{ Min } & \multicolumn{3}{|c|}{$\overline{M a x}$} \\
\hline & \multirow{2}{*}{$\begin{array}{c}1971- \\
2000\end{array}$} & \multicolumn{2}{|c|}{ 2071-2100 } & \multirow{2}{*}{$\begin{array}{c}1971- \\
2000\end{array}$} & \multicolumn{2}{|c|}{ 2071-2100 } & \multirow{2}{*}{$\begin{array}{c}1971- \\
2000\end{array}$} & \multicolumn{2}{|c|}{ 2071-2100 } \\
\hline & & RCP4.5 & RCP8.5 & & RCP4.5 & RCP8.5 & & RCP4.5 & RCP8.5 \\
\hline Kraków & 20.3 & 86 & 192 & 4.0 & 270 & 618 & 61.1 & 29 & 64 \\
\hline Brno & 37.2 & 59 & 119 & 10.5 & 161 & 288 & 83.4 & 22 & 48 \\
\hline Vienna & 45.4 & 54 & 106 & 7.2 & 196 & 456 & 82.8 & 30 & 56 \\
\hline Bratislava & 56.4 & 52 & 91 & 20.6 & 106 & 215 & 104.1 & 26 & 43 \\
\hline Szeged & 50.1 & 58 & 108 & 7.8 & 212 & 906 & 123.4 & 16 & 29 \\
\hline
\end{tabular}

Explanations: mean - mean value for the whole domain of a certain city (see Fig. 1), min - the lowest value found in a domain, max - the highest value found in the domain

\section{CONCLUSIONS}

According to the predictions presented, an increase in heat load, expressed in mean annual number of summer days, is expected in urban areas of Central Europe. Mean values for particular study areas are expected to increase by 2100 , comparing to $1971-2000$, by 20 50 days, depending on the scenario used. The regional spatial pattern of the predicted values of mean annual number of summer days shows dependence on latitude, i.e. for cities located in the northern part of the study area, the values are lower than for cities located in the south. The difference for mean values, for particular study areas, reaches about 40 days. The local spatial pattern shows the impact of both land use/land cover and relief. The largest values of mean annual number of summer days are observed in areas with intense built-up which are located in the valley floors. In rural areas, larger values are observed in the valleys than in the hill tops. The differences between the places with the lowest value and the largest value in particular cities reach 60-100 days, depending on the scenario used. 
The results obtained might be useful e.g. in spatial planning in particular cities, but they should be also used for a long-term education of local communities. The predicted changes call for preparedness and planning of the mitigation actions. Those are actions which cannot be realized without a relatively high level of public awareness of the issue discussed. First of all, the density of existing built-up structures should not be increased as it might generate in the future the intensification of the heat load. New buildings should be located in areas located well above the river valley floor, so as to avoid the enhancement of heat load increase by overlapping effect of both relief and land use. Additionally, each city should elaborate a "strategy of shading", e.g. by increasing the number of trees. Urban green areas may contribute to the decrease of heat load only when they are arranged in such a way as to increase the city albedo, i.e. reflect the solar radiation and do not allow it to be absorbed by the urban structures.

The area of Central Europe is very diversified in terms of the natural environment conditions. Effects of factors of regional importance are modified significantly by the impact of various local conditions. The results presented above for the five cities of Central Europe show, on one hand, the high diversity of the region, but on the other hand, they present a tendency common for the whole area of Central Europe, namely the predicted increase in the heat load in urban areas. Those results are in accordance with results available for the whole continent. Therefore, further research on potential consequences of that phenomenon is needed, together with the transfer of this scientific knowledge to the decision makers, responsible for spatial planning and citizens' health and well-being.

Acknowledgements: The project "Urban climate in Central European cities and global climate change" (http://www.klimat.geo.uj.edu.pl/urbanclimate/index.html) has been realized within the framework of the International Visegrad Fund's Standard Grant No. 21410222 in the years 2014-2015. The study was supported by National Research, Development and Innovation Office (NKFI K-120346).

\section{REFERENCES}

Auer I, Böhm R, Mohnl H (1989) Eine anwendungsorientierte Klimatographie. Magistrat der Stadt Wien, Wien Baccini M, Biggeri A, Accetta G, Kosatsky T, Katsouyanni K, Analitis A, Anderson HR, Bisanti L, D'Ippoliti D, Danova J, Forsberg B, Medina S, Paldy A, Rabczenko D, Schindler C, Michelozzi P (2008) Heat effects on mortality in 15 European cities. Epidemiology 19:711-719

Bechtel B, Daneke C (2012) Classification of local climate zones based on multiple earth observation data. JSTARS 5:1191-1202

Bechtel B, Alexander PJ, Böhner J, Ching J, Conrad O, Feddema J, Mills G, See L, Stewart I (2015) Mapping local climate zones for a worldwide database of the form and function of cities. ISPRS Int J Geo-Inf 4: 199-219

Böhm R (1998) Urban bias in temperature time series: a case study for the City of Vienna, Austria. Climatic Change 38:113-128

Bokwa A (2010a) Effects of air pollution on precipitation in Kraków (Cracow), Poland in the years 1971-2005, Theor Appl Climatol 101:289-302

Bokwa A (2010b) Wieloletnie zmiany struktury mezoklimatu miasta na przykładzie Krakówa. [Multi-annual changes of the urban mesoclimate structure using an example of Kraków (in Polish)] Institute of Geography and Spatial Management, Jagiellonian University, Kraków

Bokwa A, Hajto MJ, Walawender JP, Szymanowski M (2015) Influence of diversified relief on the urban heat island in the city of Kraków, Poland. Theor Appl Climatol 122:365-382

Clarke L, Edmonds J, Jacoby H, Pitcher H, Reilly J, Richels R (2007) Scenarios of Greenhouse Gas Emissions and Atmospheric Concentrations. Sub-report 2.1A of Synthesis and Assessment Product 2.1 by the U.S. Climate Change Science Program and the Subcommittee on Global Change Research. Department of Energy, Office of Biological \& Environmental Research, Washington D.C. 
Bokwa A, Dobrovolný P, Gál T, Geletič J, Gulyás Á, Hajto MJ, Holec J, Hollósi B, Kielar R, Lehnert M, Skarbit N, Štastný P, Švec M, Unger J, Walawender JP, Žuvela-Aloise $M$

Dobrovolný P, Řezníčková L, Brázdil R, Krahula L, Zahradníček P, Hradil M, Doleželová M, Šálek M, Štěpánek P, Rožnovský J, Valášek H, Kirchner K, Kolejka J (2012) Klima Brna. Víceúrovňová analýza městského klimatu. [The Climate of Brno. Multilevel analysis of urban climate (in Czech)] Masaryk University, Brno

Dobrovolný P (2013) The surface urban heat island in the city of Brno (Czech Republic) derived from land surface temperatures and selected reasons for its spatial variability. Theor Appl Climatol 112:89-98

Formayer H, Haas P (2009) Correction of RegCM3 model output data using a rank matching approach applied on various meteorological parameters. In: Deliverable D3.2 RCM output localization methods (BOKUcontribution of the FP 6 CECILIA project)

Früh B, Becker P, Deutschländer T, Hessel JD, Kossmann M, Mieskes I, Namyslo J, Roos M, Sievers U, Steigerwald T, Turau H, Wienert U (2011) Estimation of climate-change impacts on the urban heat load using an urban climate model and regional climate projections. J Appl Meteor Climatol 50:167-184

Gross G (1989) Numerical simulation of the nocturnal flow systems in the Freiburg area for different topographies. Beitr Phys Atmos 62:57-72

IPCC (2013) Climate Change 2013: The Physical Science Basis. Contributionof Working Group I to the Fifth Assessment Report of the Intergovernmental Panel on Climate Change. Cambridge University Press, Cambridge, New York

Jacob D, Petersen J, Eggert B, Alias A, Christensen OB, BouwerL, Braun A, Colette A, Déqué M, Georgievski G, Georgopoulou E, Gobiet A, Menut L, Nikulin G, Haensler A, Hempelmann N, Jones C, Keuler K, Kovats S, Kröner N, Kotlarski S, Kriegsmann A, Martin E, Meijgaard E, Moseley C, Pfeifer S, Preuschmann S, Radermacher C, Radtke K, Rechid D, Rounsevell M, Samuelsson P, Somot S, Soussana JF, Teichmann C, Valentini R, Vautard R, Weber B, Yiou P (2013) EURO-CORDEX: new high-resolution climate change projections for European impact research Regional Environmental Change. Springer, Berlin, Heidelberg

Kottek M, Grieser J, Beck C, Rudolf B, Rubel F (2006) World Map of the Köppen-Geiger climate classification updated. Meteorol Z 15:259-263

Lapin M, Melo M (2011) Climate change and its possible impacts on the urban areas in SW Slovakia. Institute of Geography and Spatial Management, Jagiellonian University, Kraków

Geletič J, Lehnert M (2016). GIS-based delineation of local climate zones: The case of medium-sized Central European cities. Moravian Geogr Rep 24:2-12

Lelovics E, Unger J, Gál T, Gál CV (2014) Design of an urban monitoring network based on Local Climate Zone mapping and temperature pattern modelling. Clim Res 61: 51-62

Moss RH, Edmonds JA, Hibbard KA, Manning MR, Rose SK, van Vuuren DP, Carter TR, Emori S, Kainuma M, Kran T, Mechl GA, Mitchell JFB, Nakicenovic N, Riahi K, Smith SJ, Stouffer RJ, Thomson AM, Weyant JP, Wilbanks TJ (2010) The next generation of scenarios for climate change research and assessment. Nature 463:747-756

Riahi K, Gruebler A, Nakicenovic N (2007) Scenarios of long-term socio-economic and environmental development under climate stabilization. Technol Forecast Socl 74:887-935

Siebert J, Sievers U, Zdunkowski W (1992) A one-dimensional simulation of the interaction between land surface processes and the atmosphere. Bound-Lay Meteorol 59:1-34

Sievers U, Forkel R, Zdunkowski W (1983) Transport equations for heat and moisture in the soil and their application to boundary layer problems. Beitr Phys Atmos 56:58-83

Sievers U, Zdunkowski W (1985) A numerical simulation scheme for the albedo of city street canyons. BoundLay Meteorol 33:245-257

Sievers U (1990) Dreidimensionale Simulationen in Stadtgebieten. Umwelt-meteorologie, Schriftenreihe Band 15: Sitzung des Hauptausschusses II am 7. und 8. Juni in Lahnstein. Kommission Reinhaltung der Luft im VDI und DIN, Düsseldorf

Sievers U (1995) Verallgemeinerung der Stromfunktionsmethode auf drei Dimensionen. Meteorol Z 4:3-15

Sievers U, Früh B (2012) A practical approach to compute short-wave irradiance interacting with subgrid-scale buildings. Meteorol Z 21:349-364

Smith SJ, Wigley TML (2006) Multi-gas forcing stabilization with the MiniCAM. Energy J 27:373-391

Stadt Wien (2015) Wirtschaft, Arbeit und Statistik (Magistratsabteilung 23): Wien in Zahlen 2015. Stadt Wien, Wien

Stewart ID (2011) A systematic review and scientific critique of methodology in modern urban heat island literature. Int J Climatol 31:200-217

Stewart ID, Oke TR (2012) Local Climate Zones for urban temperature studies. B Am Meteorol Soc 93:1879-1900

Swire D (2006) Bratislava Blast. In: Finance New Europe

Unger J (2004) Intra-urban relationship between surface geometry and urban heat island: review and new approach. Clim Res 27:253-264 
Unger J, Savić S, Gál T (2011) Modelling of the annual mean urban heat island pattern for planning of representative urban climate station network. Adv Meteorol 2011:398613

Unger J, Savić S, Gál T, Milošević D (2014) Urban climate and monitoring network system in Central European cities. University of Novi Sad, University of Szeged, Novi Sad, Szeged

Urban population growth (2015) Global Health Observatory (GHO) data. World Health Organization

van Vuuren DM, den Elzen P, Lucas B, Eickhout B, Strengers B, van Ruijven S, Wonink R, van Houdt (2007) Stabilizing greenhouse gas concentrations at low levels: an assessment of reduction strategies and costs. Climatic Change 109:77-94

Walawender JP, Szymanowski M, Hajto MJ, Bokwa A (2014) Land surface temperature patterns in the urban agglomeration of Kraków (Poland) derived from Landsat-7/ETM+ Data. Pure Appl Geophys 171:913940

Wise MA, Calvin KV, Thomson AM, Clarke LE, Bond-Lamberty B, Sands RD, Smith SJ, Janetos AC, Edmonds JA (2009) Implications of limiting CO2 concentrations for land use and energy. Science 324:1183-1186

Žuvela-Aloise M, Koch R, Neureiter A, Böhm R, Buchholz S (2014) Reconstructing urban climate of Vienna based on historical maps dating to the early instrumental period. Urban Clim 10:490-508 